\title{
Synthesis of Janus compounds for the recognition of G-U mismatched nucleobase pairs
}

Gerard Artigas, and Vicente Marchán*

Departament de Química Orgànica, Facultat de Química, Universitat de Barcelona Martí i Franquès 1-11, E-08028 Barcelona, Spain

vmarchan@ub.edu

TOC ABSTRACT GRAPHIC

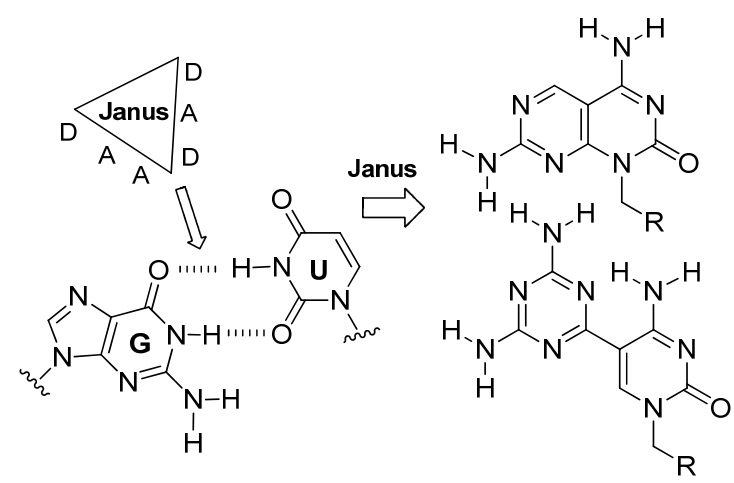

\begin{abstract}
The design and synthesis of two Janus-type heterocycles with capacity to simultaneously recognize guanine and uracyl in G-U mismatched pairs through complementary hydrogen bond pairing is described. Both compounds were conveniently functionalized with a carboxylic function and efficiently attached to a tripeptide sequence by using solid-phase methodologies. Ligands based on the derivatization of such Janus compounds with a small aminoglycoside, neamine, and its guanidinylated analogue have been synthesized, and their interaction with Tau RNA has been investigated by using several biophysical techniques, including UV-monitored melting curves, fluorescence titration experiments and ${ }^{1} \mathrm{H}$ NMR. The overall results indicated that Janus-neamine/guanidinoneamine showed some preference for the +3 mutated RNA sequence associated with the development of some tauopathies, although preliminary NMR studies have not confirmed binding to G-U pairs. Moreover, a good correlation has been found between the RNA binding affinity of such
\end{abstract}


Janus-containing ligands and their ability to stabilize this secondary structure upon complexation.

\section{INTRODUCTION}

Targeting RNA with small molecules, particularly human disease-causing RNAs, has enormous potential in medicinal chemistry. ${ }^{1}$ In addition to the notable case of compounds targeting bacterial ribosomal $\mathrm{RNA}^{1}$, recent examples have demonstrated that the function of other RNA sequences can be modulated with synthetic small molecules. ${ }^{2}$ Similarly to proteins, RNA is able to fold local structural motifs such as stem-loops, bulges or internal loops into complex three-dimensional architectures, thus generating targetable binding sites where ligands can be accommodated. The simultaneous recognition of such targetable motifs by compounds based on the combination of fragments is an attractive approach to develop ligands with increased RNA affinity and specificity. ${ }^{1,3}$ Moreover, this fragmentbased approach might also be used to confer them with desirable drug-like properties such as cellular permeability. ${ }^{4}$

Among the large variety of RNA structural motifs, the G-U wobble base-pair ${ }^{5}$ plays an essential role in many biological processes since it is recognized by proteins and other RNAs. ${ }^{6}$ Despite its comparable thermodynamic stability to Watson-Crick base pairs, several studies have revealed that G-U wobble pairs are more prone to base-opening than canonical pairs, ${ }^{7}$ which would facilitate their recognition through complementary hydrogen bond pairing by using nicknamed Janus-type molecules. As the two-faced Roman god, Janus-type heterocycles have two hydrogen bonding arrays complementary to the faces of a given pair of nucleobases. ${ }^{8}$ Insertion of such compounds between the two nucleobases is expected to provide higher affinity and specificity since the number of hydrogen bonds will be increased. Most of Janus molecules reported have been incorporated into DNA, PNA analogues or peptides with negatively-charged backbone with the aim of forming triplex or duplex structures upon bifacial recognition of target nucleobases. ${ }^{9}$ Diaminotriazine conjugation to an acridine derivative has also been explored for targeting U-U mismatch sites in CUG repeats in RNA associated with the development of myotonic dystrophy type 1 disease. $^{10}$ 
A

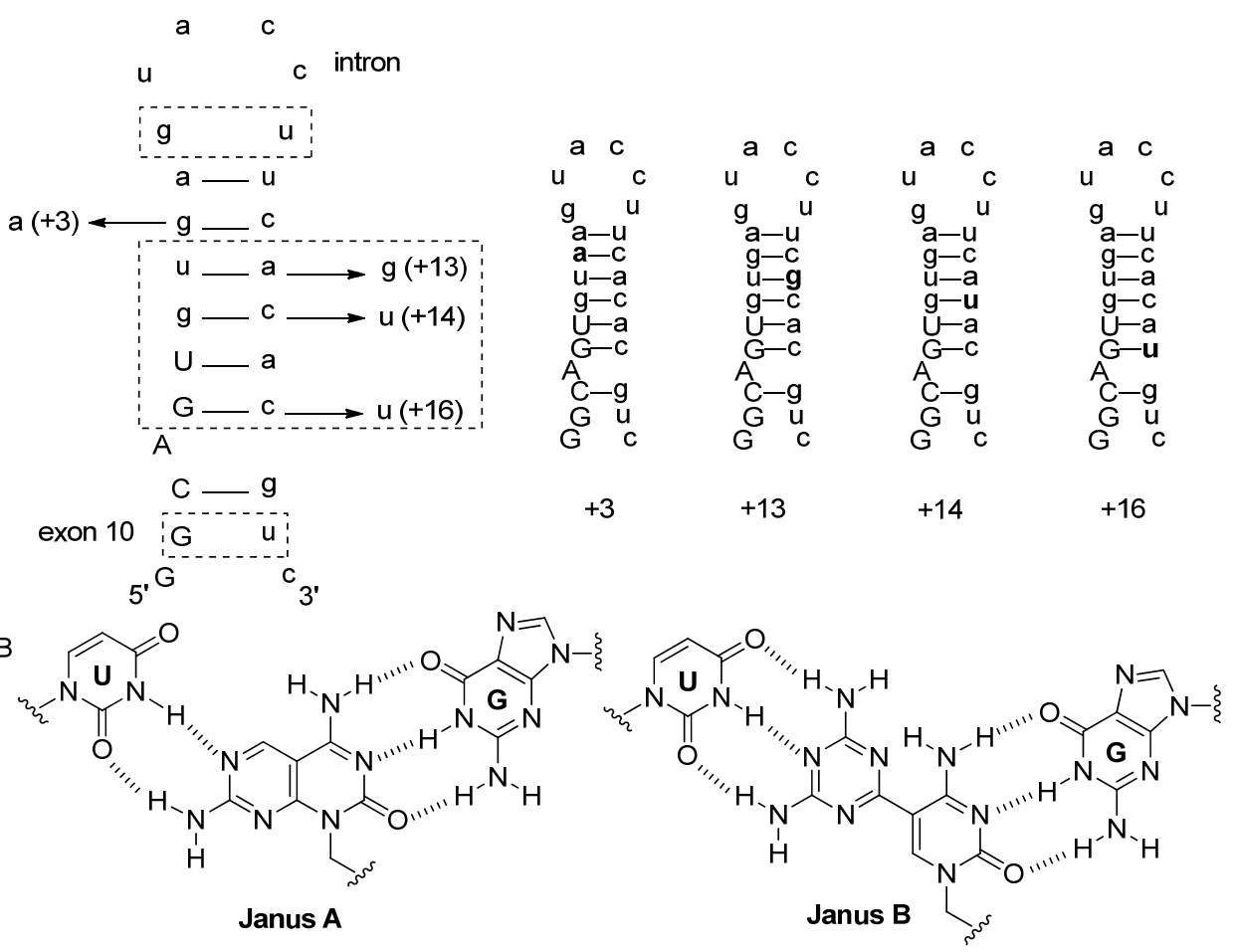

Figure 1. A) Sequences and secondary structure of wild-type (wt) and $+3,+13,+14$ and +16 mutated Tau stem-loop RNAs. Exonic sequences are shown in capital letters and intronic sequences in lower case. Nucleotides involved in base pairs identified previously by NMR are connected by a dash. ${ }^{12 a, 13 c}$ B) Schematic representation of Janus A and Janus B heterocycles binding to G-U mismatched pairs.

Of current interest to our laboratory ${ }^{11}$ is the development of ligands for the RNA secondary structure located at the exon $10-5^{\prime}$ ' intron junction of Tau pre-mRNA since it has been proposed as a therapeutic target for the treatment of several tauopathies, including frontotemporal dementia with parkinsonism linked to chromosome 17 (FTDP-17). 12,13 Interestingly, wild-type Tau RNA has two G-U pairs (G+5 and G-4), and some of the disease-causing mutations $(+13,+14$ and +16$)$ found in FTDP-17 patients form additional G-U pairs (see Figure 1) that diminish the thermodynamic stability of the stem-loop structure. This modifies exon 10 alternative splicing and, as a consequence, the correct ratio of tau protein isoforms is altered, which leads to dementia. ${ }^{14}$ Significantly, early NMR studies reported by Varani et al. ${ }^{12 a}$ suggested that wobble G-U pairs are only formed in the case of +13 and +14 mutated sequences, whereas G-1 ( +16 mutated sequence) and G +5 and G-4 (wt, +3 and +16) are not paired with their faced U's. On the basis of these precedents, we have envisaged that such G-U pairs might be used to selectively target Tau RNA with 
Janus-type molecules designed to recognize both mismatched nucleobases (Figure 1). It is expected that stabilization of the mutated RNA sequences upon ligand binding might allow the physiological balance of tau isoforms to be restored and consequently the tauopathy to be treated. ${ }^{11-14}$ We report herein the design and synthesis, and, to the best of our knowledge, the first Janus-type molecules (denoted in this work as Janus A and Janus B) capable of hydrogen bond to G's and U's in G-U mismatched pairs. Ligands based on the derivatization of such Janus compounds with a small aminoglycoside, neamine, and its guanidinylated analogue have been synthesized, and their interaction with Tau RNA has been investigated by using several biophysical techniques.

\section{RESULTS AND DISCUSSION}

\section{Synthesis and characterizacion of Janus building blocks 1 and 2.}

As shown in Figure 1, the heteroaromatic bicyclic Janus A molecule contains donoracceptor-acceptor and acceptor-donor H-bond arrays. Regarding Janus B molecule we chose to incorporate both faces in separate aryl rings linked through a single bond, which might confer some degree of rotational flexibility. It should be noted that the formation of an intramolecular H-bond between the exocyclic amino function of cytosine and the adjacent nitrogen of the diaminotriazine heterocycle might serve to keep it planar and semirigid, which might be important for recognition of G-U mismatched pairs. In this case, diaminopurine face (donor-acceptor-donor H-bond array) was chosen to afford three Watson-Crick hydrogen bonds upon binding to uracyl, whereas cytosine face (donoracceptor-acceptor H-bond array) can form the three typical Watson-Crick hydrogen bonds with guanine, as in Janus A. Hence, Janus A and Janus B-containing compounds might have the potential to form 5 or 6 hydrogen bonds with G-U mismatched pairs, respectively. Since the final aim is to combine such Janus structures with other molecules such as peptides or glycosides to generate ligands with increased RNA specificity, we planned the synthesis of two Janus monomers (compound 1 for Janus A in Scheme 1 and compound 2 for Janus B in Scheme 2) with a carboxylic function to allow further derivatization in solution or in a solid-phase through the formation of an amide bond.

Compound 1 was prepared in 11 steps and 68\% average stepwise yield (Scheme 1). First, barbituric acid was converted into 2,4,6-trichloropyrimidine-5-carbaldehyde (3) by Vilsmeier reaction with phosphorus oxychloride and DMF. ${ }^{15}$ Nucleophilic aromatic substitution with ethyl aminobutyrate $(1 \mathrm{~mol}$ equiv. $)$ at $0^{\circ} \mathrm{C}$ in the presence of triethylamine 
afforded simultaneous substitution at positions 2 and 4 in the pyrimidine ring. Although monosubstitution at position 4 was favoured at low temperature $\left(-78^{\circ} \mathrm{C}\right)$, MS analysis showed the formation of several side products because of the nucleophilic attack of triethylamine. This side-reaction was minimized by using a sterically-hindered base, $N, N-$ diisopropylethylamine, which yielded compound $4 \mathrm{a}$ in $60 \%$ after flash column chromatography. This compound differs from its regioisomer $4 \mathbf{b}\left(\mathrm{S}_{N} \mathrm{Ar}\right.$ at position 2$)$ in the ${ }^{1} \mathrm{H}$ NMR chemical shift of the amino function ( $\delta$ : $9.36 \mathrm{ppm}$ for $\mathbf{4 a}$ and $6.28 \mathrm{ppm}$ for $\mathbf{4 b}$ ). The 1D NOE irradiation of the proton at $9.36 \mathrm{ppm}$ showed a clear NOE enhancement of the aldehyde proton whereas that phenomenon did not occur for the proton at $6.28 \mathrm{ppm}$, which allowed the unambiguous distinction of both isomers.

A second nucleophilic aromatic substitution with aqueous ammonia afforded compound $\mathbf{5}$ in quantitative yield. It is interesting to mention that $S_{N} A r$ occurs exclusively at position 2 when the reaction is carried out at room temperature for $5 \mathrm{~h}$, whereas a large excess of ammonia and higher temperature gives substitution at positions 2 and 6. Similar results have been reported with other derivatives of 2,6-dichloropyrimidine that contain an amino substituent at position 4 and electronwithdrawing groups (aldehyde or ester) at position 5 of the ring. ${ }^{15 b, c, 16,17}$

The next step was the reduction of the aryl chloride group by $\mathrm{H}_{2}$ with $10 \% \mathrm{Pd}-\mathrm{C}$ in the presence of sodium acetate, which afforded 6 with 56\% yield after chromatographic purification. Notably, the aldehyde group was not reduced under the conditions used for carrying out catalytic hydrogenation. The primary aromatic amino function was bis-Boc protected by reaction with tert-butoxycarbonyl anhydride in DMF in the presence of a catalytic amount of DMAP. Besides 7 (29\% yield after purification), several side products were identified, including those derived from monoprotection of both amino functions. Then, the aldehyde was transformed in oxime (8) in $88 \%$ yield, and dehydration with trifluoroacetic anhydride produced the fluorescent nitrile derivative 9 (79\%). The critical step of the synthesis route involved the transformation of the free secondary amino function into an activated urea derivative to allow cyclization in basic media. To our surprise, this aromatic amine function was found very unreactive, since no evidence of reaction was obtained when using triphosgene, phosgene, trimethylsilyl isocyanate or chlorosulfonyl isocyanate. Reaction with $N$-chlorocarbonyl isocyanate ${ }^{15 b}$ at $-10^{\circ} \mathrm{C}$ in the presence of triethylamine afforded in very low yield the $N$-chlorocarbonylurea derivative. Finally, reaction with trichloroacetyl isocyanate at $0^{\circ} \mathrm{C}$ in anhydrous DCM under an $\mathrm{Ar}$ atmosphere 
produced compound $\mathbf{1 0}$ in nearly quantitative yield after flash column chromatography. Cyclization in a concentrated methanolic solution of ammonia afforded the key compound (11, 80\% yield) that contains both Janus faces. Boc-protection of the free amino group followed by basic hydrolysis of the ester yielded the final JanusA monomer $\mathbf{1}$ as a clear yellow solid, which was fully characterized by HR-ESI MS and ${ }^{1} \mathrm{H}$ and ${ }^{13} \mathrm{C}$ NMR.
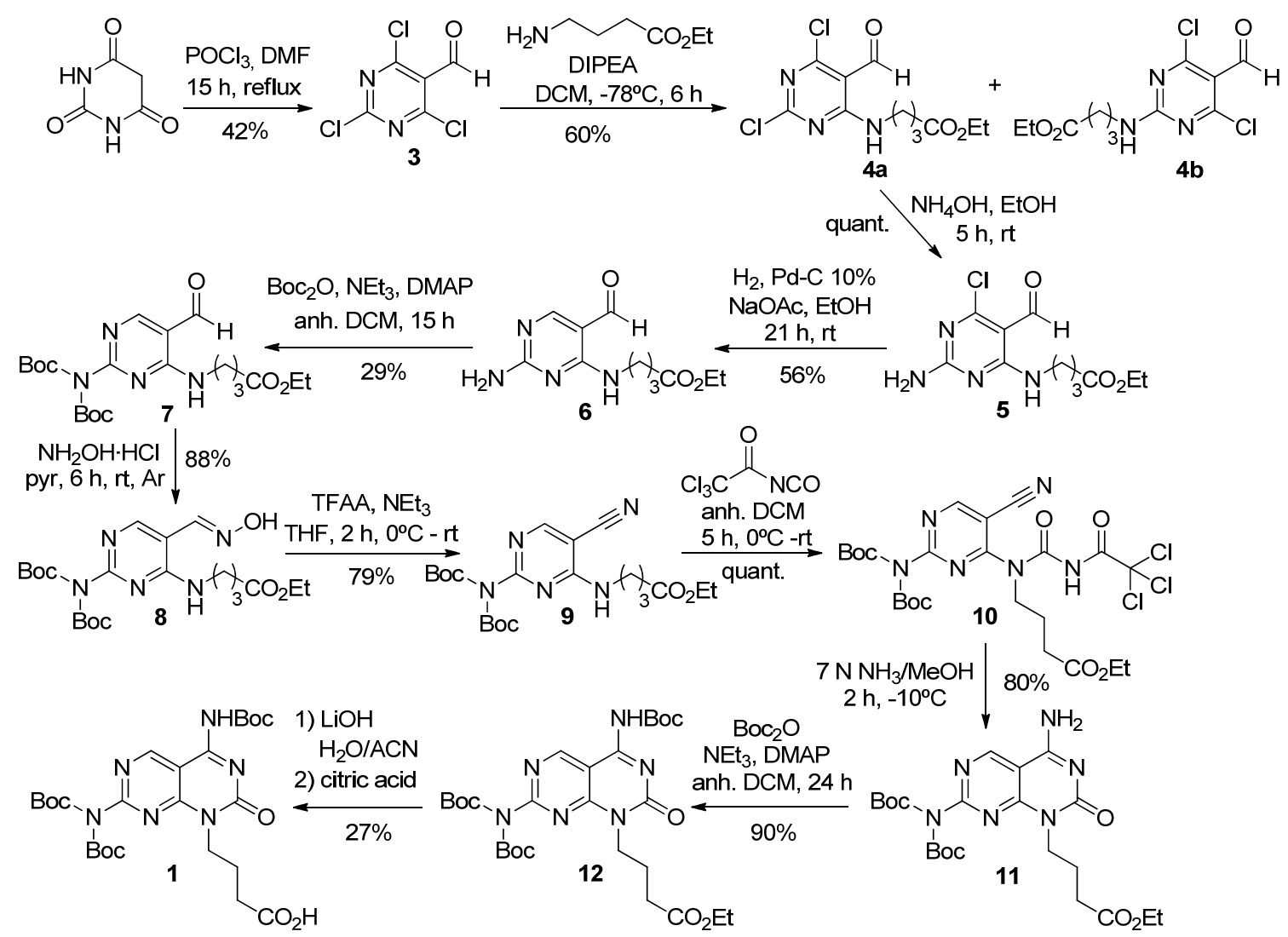

Scheme 1. Synthesis of Janus A monomer (1).

Compound 2 was prepared in 4 steps and $47 \%$ average stepwise yield (Scheme 2) from malononitrile, urea and triethyl orthoformate. The key step involved the condensation of the nitrile group of 5-cyanocytosine ${ }^{18}$ with dicyandiamide ${ }^{19}$ in dry ethylene glycol in the presence of $\mathrm{KOH}$ at $150^{\circ} \mathrm{C}$ for $40 \mathrm{~h}$, which afforded 15 as a brown solid in $54 \%$ yield. Mild condition reactions, such as those reported for the construction of diaminotriazine from 5cyanouracy $1^{19 c}$ failed in this case and more energetic conditions were required (e.g. prolonged heating at $150^{\circ} \mathrm{C}$ or assisted by microwave irradiation). The next step involved alkylation of $\mathrm{N} 1$ of the cytosine ring with ethyl bromobutyrate by using $\mathrm{NaH}$ in DMF. Hydrolysis of the intermediate with $\mathrm{LiOH}$ afforded the expected Janus B monomer (2). 
According to previous studies on the incorporation of triazine-containing amino acids onto peptides by solid-phase methodologies, ${ }^{20}$ we decided not to protect the amino groups of the triazine moiety. Interestingly, ${ }^{1} \mathrm{H}$ NMR spectra of compound $\mathbf{2}$ suggests the formation of an intramolecular hydrogen bond between the exocyclic amino group of cytosine and the N2 of the triazine ring, which might protect it from acylation during amide bond formation.

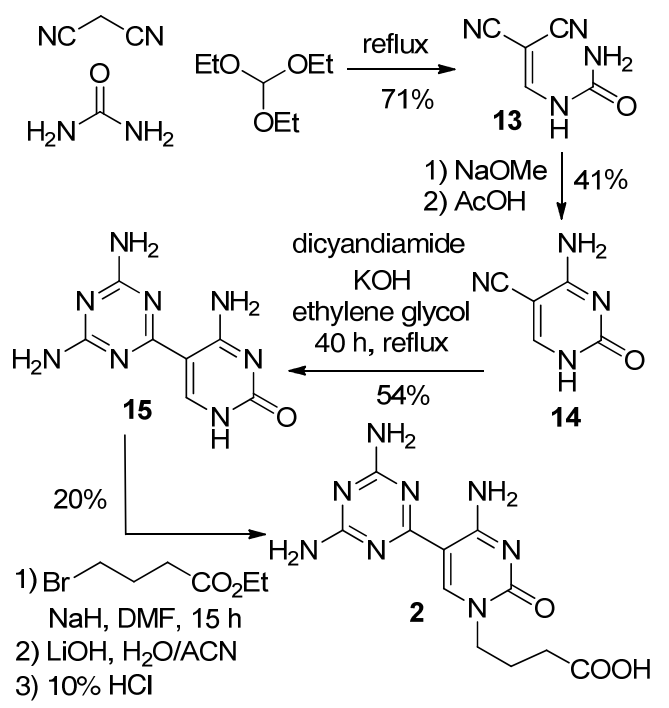

Scheme 2. Synthesis of Janus B monomer (2).

\section{Synthesis and characterizacion of Janus-containing ligands.}

Targeting G-U mismatched pairs in Tau RNA or in other RNA secondary structures with Janus-type molecules requires conferring them with capacity to selectively recognize RNA from DNA. Aminoglycosides fulfill this requirement since they are able to discriminate Atype from B-type duplexes and have relatively high affinity for RNA. ${ }^{21}$ However, these natural antibiotics lack of RNA sequence specificity, so they are considered promiscuous compounds. In spite of this drawback, aminoglycosides are privileged building blocks for designing new RNA ligands. ${ }^{22}$ Recently, we have described a series of ligands for Tau RNA based on the combination of neamine and its guanidinylated analogue, guanidinoneamine, with heteroaromatic compounds such as acridines and an azaquinolone derivative with capacity to recognize unpaired adenines. ${ }^{11}$ Based on these precedents, our next objective was the derivatization of Janus A and B heterocycles with these small glycosides. It is worth noting that replacement of the amino functions of neamine by guanidinium groups is expected to improve uptake by eukaryotic cells, as well as the RNA 
binding affinity and stabilizing capacity of the ligands. ${ }^{23}$ The synthesis of the ligands and their structures are shown in Scheme 3. Since the distance between both building blocks can be a critical parameter in ligands based on the combination of fragments, we used two thiol-containing neamine derivatives (Nea and Nea2) ${ }^{11}$ differing in the length of the spacer between the thiol group and the glycoside core.

First, both Janus heterocycles were derivatized with a cysteine-containing peptide since the reactive thiol group was planned to be used for the attachment to the aminoglycoside via the formation of a disulfide linkage. Moreover, the guanidinium and carboxamide groups provided by arginine and asparagine, respectively, could generate additional interactions with RNA (e.g. hydrogen bonding and/or electrostatic). The tripeptide was assembled on a Rink amide $p$-MBHA resin using standard Fmoc/tBu chemistry. Janus monomers 1 and 2 were efficiently attached into the $N$-terminus of the peptide by using HATU as a coupling reagent. Cleavage and deprotection with $\mathrm{TFA} / \mathrm{TIS} / \mathrm{H}_{2} \mathrm{O}$ 95:2.5:2.5 for $1 \mathrm{~h}$ at $\mathrm{rt}$, afforded the target compounds (18 and 19, Scheme 3 ) with high purity according to HPLC analysis. This confirms that it is not necessary to protect the exocyclic amino function of cytosine in monomer 2.

Janus-Neamine ligands (20-23) were easily synthesized in a two-step process which implicates two consecutive thiol-disulfide exchange reactions. First, thiol-derivatized neamine monomers (Nea or Nea2) ${ }^{11}$ were activated with 2,2'-dithiobis(5-nitropyridine) $(\mathrm{DTNP})^{24}$ under acidic conditions for $15 \mathrm{~h}$ under Ar atmosphere. Then, the disulfide intermediates were reacted with the thiol-containing Janus-peptide monomers (18 or 19), which afforded the desired ligands (20-23) after purification by reversed-phase HPLC (yields 21-53\%). All the compounds were fully characterized by NMR (1D ${ }^{1} \mathrm{H}, \mathrm{COSY}$, TOCSY) and high-resolution ESI mass spectrometry.

As shown in Scheme 3, the guanidinylated ligands (24-27) were prepared by direct guanidinylation of their precursors (20-23) following previously reported procedures. ${ }^{11 \mathrm{~b}, 25}$ A 40-fold mol equiv. excess of $N, N$ '-di-Boc- $N$ '"-triflylguanidine in the presence of triethylamine (240 mol eq.) was used in all cases. After acidic deprotection and purification by HPLC, Janus-Guanidinoneamine ligands were obtained (yields: 23-25\%) and characterized by NMR and HRMS. A significant amount of the triguanidinylated ligand was also isolated, which indicates that the guanidinylation reaction did not reach completion after 4 days. 


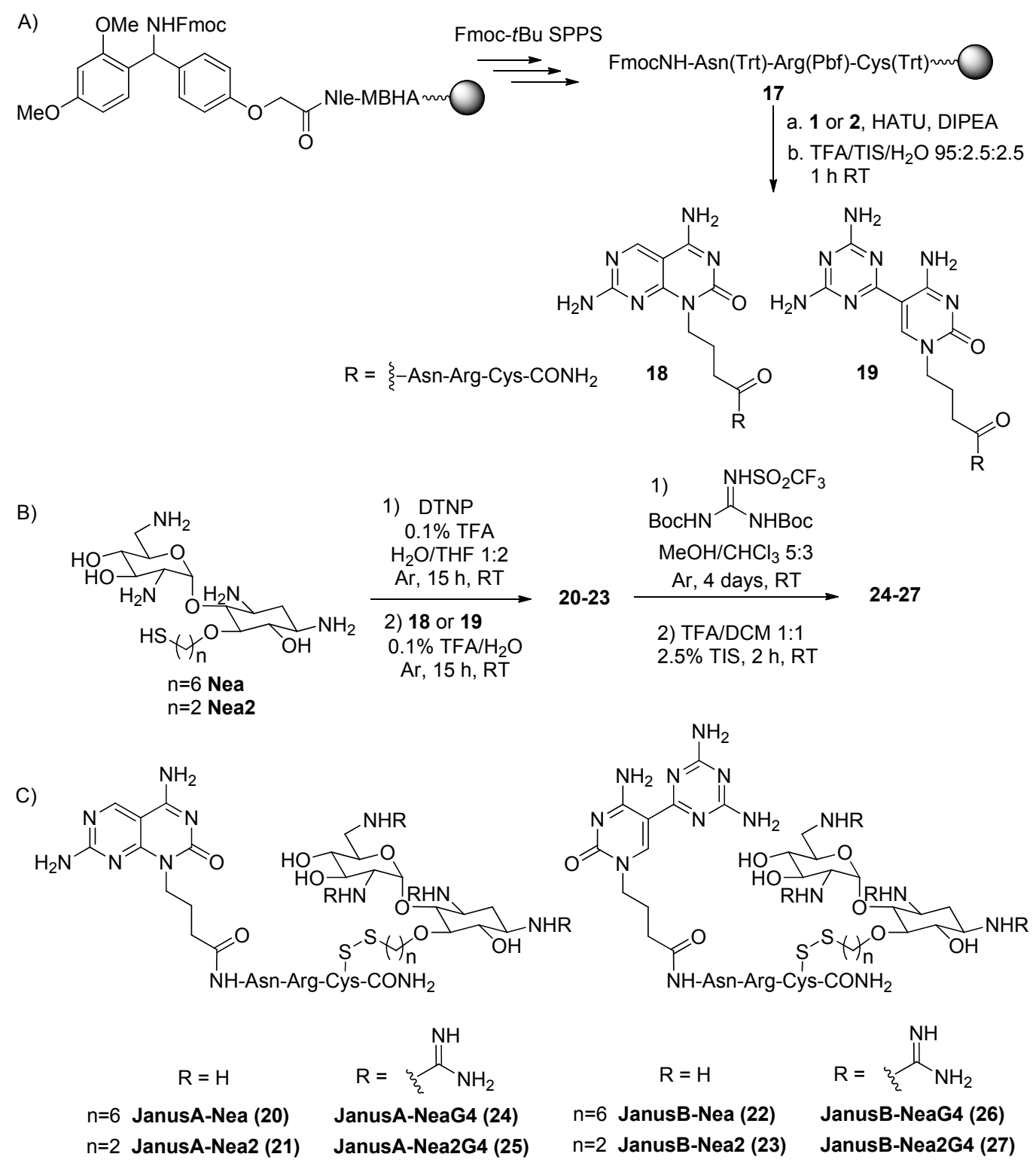

Scheme 3. Synthesis of Janus-Neamine/Guanidinoneamine ligands. A) Solid-phase synthesis of thiol-containing Janus-peptide derivatives; B) synthesis, and C) structure of Janus-containing ligands.

\section{Studies on the interaction of Janus-containing ligands with Tau RNA.}

Our next objective was to study the interaction of Janus-Neamine ligands (20-23) and their guanidinylated derivatives, Janus-Guanidinoneamine (24-27), with Tau RNA, and in particular to evaluate their ability to stabilize Tau RNA. Besides wt we choose two of the mutated sequences associated with the development of tauopathies, +3 and +16 . As previously mentioned, all of them contain two G-U mismatched pairs and +16 mutation 
generates an additional G-U mismatched pair adjacent to the bulged adenine. UV melting experiments were carried out by monitoring the absorbance at $260 \mathrm{~nm}$ as a function of temperature, which allowed to determine the melting temperature $\left(\mathrm{T}_{\mathrm{m}}\right)$ as indicative of the thermal stability of the RNA secondary structure (Figure 2). $\Delta \mathrm{T}_{\mathrm{m}}$ values in Table 1 show the effect of the ligands on the $\mathrm{T}_{\mathrm{m}}$ of RNA upon complexation.

A

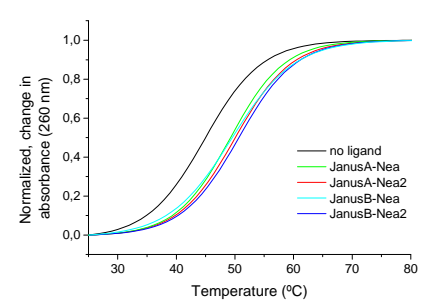

B

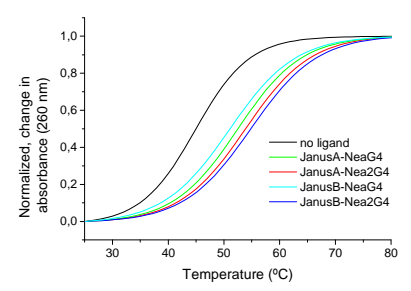

C

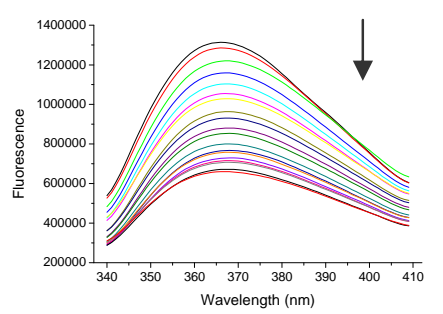

Figure 2. A) UV melting profiles for the +3 mutated RNA sequence and its ligand complexes with Janus-Neamine and B) Janus-Guanidinoneamine ligands at a [ligand]/RNA ratio of 1.0. C) Fluorescence quenching of +3 RNA labelled with 2-aminopurine-2'-deoxyribonucleotide in the loop upon addition of increasing concentrations of JanusB-Nea2. Measurements were performed with an RNA concentration of $83 \mathrm{nM}$ and ligand concentrations ranging from 0 to $5.43 \mu \mathrm{M}$ in 10 $\mathrm{mM}$ sodium phosphate buffer $\mathrm{pH} 6.8,50 \mathrm{mM} \mathrm{NaCl}$ and $0.1 \mathrm{mM} \mathrm{Na}_{2}$ EDTA.

Table 1. Melting temperatures $\left(\mathrm{T}_{\mathrm{m}}\right)$ for the complexation of the ligands with Tau RNAs (1 $\mu \mathrm{M}$ both in RNA and in ligands in $10 \mathrm{mM}$ sodium phosphate buffer, $\mathrm{pH} 6.8,50 \mathrm{mM} \mathrm{NaCl}$ and $0.1 \mathrm{mM} \mathrm{Na}_{2}$ EDTA).

\begin{tabular}{|c|c|c|c|c|c|c|}
\hline & $\mathrm{T}_{\mathrm{m}} \mathrm{wt}$ & $\Delta \mathrm{T}_{\mathrm{m}}^{[\mathrm{a}]}$ & $\mathrm{T}_{\mathrm{m}}+3$ & $\Delta \mathrm{T}_{\mathrm{m}}^{[\mathrm{a}]}$ & $\mathrm{T}_{\mathrm{m}}+16$ & $\Delta \mathrm{T}_{\mathrm{m}}^{[\mathrm{a}]}$ \\
\hline No ligand & 63.0 & - & 44.3 & - & 56.6 & \\
\hline Neamine & 62.8 & -0.2 & 48.1 & +3.8 & 56.8 & +0.2 \\
\hline JanusA-Nea & 63.1 & +0.1 & 49.3 & +5.0 & 58.5 & +1.9 \\
\hline JanusA-Nea2 & 63.6 & +0.6 & 50.4 & +6.1 & 57.6 & +1.0 \\
\hline JanusB-Nea & 62.8 & -0.2 & 49.6 & +5.3 & 58.0 & +1.4 \\
\hline JanusB-Nea2 & 63.4 & +0.4 & 50.4 & +6.1 & 57.6 & +1.0 \\
\hline
\end{tabular}

${ }^{[a]} \Delta T_{m}=\left(T_{m}\right.$ of the RNA in the presence of ligand $)-\left(T_{m}\right.$ of RNA alone $)$. 
As shown in Table 1, the effect of Janus-Neamine ligands on the thermal stability of wt RNA was almost negligible, being similar to that obtained with the free aminoglycoside. However, this effect was positive in the case of the mutated sequences being particularly higher with the +3 mutant. Interestingly, the effect of the length of the spacer linking both fragments was different depending on the nature of the RNA sequence: the shorter spacer caused a greater increase in the $\mathrm{T}_{\mathrm{m}}$ values for $+3 \mathrm{RNA}\left(\Delta \mathrm{T}_{\mathrm{m}}=+5.0^{\circ} \mathrm{C}\right.$ for JanusA-Nea $v s$ $\Delta \mathrm{T}_{\mathrm{m}}=+6.1^{\circ} \mathrm{C}$ for JanusA-Nea2) whereas the opposite tendency was found for $+16 \mathrm{RNA}$ $\left(\Delta \mathrm{T}_{\mathrm{m}}=+1.9^{\circ} \mathrm{C}\right.$ for JanusA-Nea $v s \Delta \mathrm{T}_{\mathrm{m}}=+1.0^{\circ} \mathrm{C}$ for JanusA-Nea2). This suggests that the binding site of these compounds might be different depending on the secondary structure of the RNA target. To our surprise, the stabilizing ability of the ligands was independent on the nature of the Janus-type heterocycle. However, the fact that the $T_{m}$ values of JanusNeamine ligands were slightly higher than those of neamine alone with +3 and +16 RNAs seems to suggest that the Janus-peptide fragment might participate in RNA binding. Moreover, the higher stabilization of +3 RNA compared with that of +16 (e.g. JanusANea2, $\Delta \mathrm{T}_{\mathrm{m}}=+6.1^{\circ} \mathrm{C}$ for $+3 \mathrm{vs} \Delta \mathrm{T}_{\mathrm{m}}=+1.0^{\circ} \mathrm{C}$ for +16 ) might be a consequence of some kind of selectivity for this RNA mutated sequence.

These results prompted us to evaluate the ability of Janus-Guanidinoneamine ligands (2427) to stabilize the +3 mutated sequence. As shown in Table 2, guanidinylation of the aminoglycoside moiety in Janus-Neamine ligands had always a positive effect on the thermal stability of the RNA upon complexation. This effect was particularly important in the two ligands with the shorter spacer independently of the Janus heterocycle $\left(\Delta \mathrm{T}_{\mathrm{m}} \mathrm{G}=\right.$ $+3.8{ }^{\circ} \mathrm{C}$ for JanusA-Nea2G4 and JanusB-Nea2G4). However, the additional stabilization provided by the guanidinium groups was lower in the case of the ligand with the longer spacer that contains JanusB heterocycle (e.g. $\Delta \mathrm{T}_{\mathrm{m}} \mathrm{G}=+3.3^{\circ} \mathrm{C}$ for JanusA-NeaG4 vs $\Delta \mathrm{T}_{\mathrm{m}} \mathrm{G}$ $=+1.4^{\circ} \mathrm{C}$ for JanusB-NeaG4). 
Table 2. Melting temperatures $\left(\mathrm{T}_{\mathrm{m}}\right)$ for the complexation of ligands with target RNAs (1 $\mu \mathrm{M}$ both in RNA and in ligands in $10 \mathrm{mM}$ sodium phosphate buffer, $\mathrm{pH} 6.8,50 \mathrm{mM} \mathrm{NaCl}$ and $0.1 \mathrm{mM} \mathrm{Na}_{2}$ EDTA).

\begin{tabular}{cccc}
\hline & $\mathrm{T}_{\mathrm{m}}+3$ & $\Delta \mathrm{T}_{\mathrm{m}}{ }^{[\mathrm{a}]}$ & $\Delta \mathrm{T}_{\mathrm{m}} \mathrm{G}^{[\mathrm{b}]}$ \\
\hline No ligand & 44.3 & - & - \\
Guanidinoneamine & 50.1 & +5.8 & +2.0 \\
JanusA-NeaG4 & 52.6 & +8.3 & +3.3 \\
JanusA-Nea2G4 & 54.2 & +9.9 & +3.8 \\
JanusB-NeaG4 & 51.0 & +6.7 & +1.4 \\
JanusB-Nea2G4 & 54.2 & +9.9 & +3.8 \\
\hline
\end{tabular}

${ }^{[a]} \Delta T_{m}=\left(T_{m}\right.$ of the RNA in the presence of ligand $)-\left(T_{m}\right.$ of RNA alone $)$.

${ }^{[b]} \Delta T_{m} G=\left(T_{m}\right.$ of the RNA in the presence of the guanidinylated ligand $)-\left(T_{m}\right.$ of the RNA in the presence of the parent non-guanidinylated ligand).

In order to check if the guanidinylated derivatives have higher binding affinity than their parent amino compounds, quantitative binding studies were carried out by fluorescence titration experiments with the +3 mutated RNA since, as previously mentioned, $T_{m}$ values suggested some preference for this oligoribonucleotide sequence. Based on previous studies with other Tau RNA ligands, ${ }^{11}$ we decided to label +3 Tau RNA with fluorescein since a characteristic dose-dependent saturatable quenching in the fluorescence of the RNA is usually observed upon complexation with the ligands. ${ }^{26}$ This approach allows EC $_{50}$ values (the effective ligand concentration required for 50\% RNA response) to be obtained by fitting the data to a sigmoidal dose-response curve. To our surprise, upon addition of increasing concentrations of Janus-containing ligands, either Janus A or Janus B, the fluorescence intensity of the fluorescein-labeled RNA increased (upon excitation at 490 $\mathrm{nm})$ and the maximum was shifted from the typical $517 \mathrm{~nm}$ value to $522-525 \mathrm{~nm}$. This behaviour might be attributed to the presence of several binding sites in the RNA structure or to the interaction of the ligands with fluorescein. ${ }^{26}$ As an alternative to fluorescein, we choose the fluorescent nucleotide analogue 2-aminopurine-2'-deoxyribonucleotide (2-AP), which has also been widely used to determine binding affinities for RNA. ${ }^{27}$ In order to minimize alterations in the structure and stability of +3 Tau RNA, we decided to replace the adenine base of the loop with 2-AP. Again, changes in 2-AP fluorescence intensity upon excitation at $290 \mathrm{~nm}$ were measured as a function of the concentration of the ligands. 
Unfortunately, the inherent fluorescence of JanusA heterocycle hampered the accurate determination of $\mathrm{EC}_{50}$ values for JanusA-containing ligands. However, the binding affinities of the four JanusB-containing ligands (Table 3) could be determined with 2-APlabelled +3 RNA. As shown in Figure 2, the fluorescence of 2-AP decreased upon addition of increasing concentrations of the ligands, while the wavelength of the fluorescence maximum stayed constant. In this case, the inherent fluorescence of the ligand could be efficiently substracted from that of the labelled RNA by repeating the full titration in the absence of RNA. Two main conclusions can be drawn from $\mathrm{EC}_{50}$ values reported in Table 3. First, binding affinities of the ligands are relatively high (120-300 nM) and the length of the spacer seems to be a critical parameter since the binding was observed to be stronger for the ligands containing the shorter spacer linking both fragments, independently of the glycoside moiety $\left(\mathrm{EC}_{50}=296 \mathrm{nM}\right.$ for JanusB-Nea vs $\mathrm{EC}_{50}=213 \mathrm{nM}$ for JanusB-Nea2). Second, guanidinylation of the aminoglycoside had a positive influence on binding affinity, which was slightly higher in the case of the ligand with the shorter spacer $\left(\mathrm{EC}_{50}=213 \mathrm{nM}\right.$ for JanusB-Nea2 vs $\mathrm{EC}_{50}=122 \mathrm{nM}$ for JanusB-Nea2G4).

Table 3. Binding of the ligands to +3 RNA.

\begin{tabular}{cc}
\hline Ligand & $\mathrm{EC}_{50}(\mathrm{nM})^{[\mathrm{a}]}$ \\
\hline JanusB-Nea & $296.7 \pm 63$ \\
JanusB-NeaG4 & $216.2 \pm 20$ \\
JanusB-Nea2 & $213.4 \pm 45$ \\
JanusB-Nea2G4 & $122.8 \pm 19$ \\
\hline
\end{tabular}

${ }^{\text {[a] }}$ All fluorescence measurements were performed in $10 \mathrm{mM}$ sodium phosphate buffer pH 6.8, $50 \mathrm{mM} \mathrm{NaCl}$ and $0.1 \mathrm{mM} \mathrm{Na}_{2}$ EDTA.

All together, these results show a good correlation between binding affinities of JanusBcontaining ligands and their ability to stabilize Tau RNA. Indeed, the $T_{m}$ values of +3 RNA were increased in the presence of the ligands that had shown higher binding affinities. Although binding affinities could not be determined for JanusA-containing ligands, according to $\mathrm{T}_{\mathrm{m}}$ values reported in Tables 1 and 2, it is expected for these compounds to have similar $\mathrm{EC}_{50}$ values than JanusB-containing ligands.

Finally, preliminary NMR studies were carried out to check if Janus-containing ligands can recognize G-U mismatched pairs through the formation of complementary hydrogen bonds. 
On the lack of a well-defined structure for the +3 mutated sequence, we choose wt RNA as a model for studying the effect of ligand addition on its 1D ${ }^{1} \mathrm{H}$ NMR spectra, particularly on the imino and aromatic region. The structure of this oligoribonucleotide and its complexes with neomycin and mitoxantrone have been studied by Varani et al., ${ }^{12 a, 13 c}$ and they can be used as a reference for interpreting changes on the NMR spectra of Tau RNA in the presence Janus-containing ligands. As shown in Figure 3, the addition of JanusA-Nea2 or JanusB-Nea2 caused a general line broadening of all signals but no significant changes in the chemical shifts of the imino protons. For example, the imino resonance of $\mathrm{G}+1(\delta$ : $12.65 \mathrm{ppm})$ and G-1 ( $\delta: 12.84 \mathrm{ppm})$ were slightly shifted in both RNA-ligand complexes ( $\delta$ : 12.55 and $12.78 \mathrm{ppm}$, respectively), whereas $\mathrm{U} 0$ and $\mathrm{U}+2$ imino resonances collapsed into a single broad signal. Additionally, changes of the chemical shifts at higher fields than the imino resonances, particularly in the region between 5.5 and $8.5 \mathrm{ppm}$, might be attributed to non-exchangeable groups of the neamine moiety. Interestingly, a new signal around $\delta: 9.55$ ppm (relative integration 1) appeared in the case of JanusB-Nea2 ligand. Taken together, these effects on the NMR spectra suggest that Janus-type heterocycles, either JanusA or JanusB, do not seem to bind any of the two G-U mismatched pairs in wt RNA since no new imino signals are formed in the region between 10 and $14 \mathrm{ppm}$. However, small changes in the chemical shifts of the imino resonances in the upper helical region (e.g., G-1, U0, G+1 and $U+2$ ) might be related with electrostatic and/or hydrogen bond interactions with RNA through the major groove, in a similar way than neomycin does. ${ }^{13 a}$ However, we can not rule out the formation of selective hydrogen bonds between Janus-type heterocycles and other RNA nucleobases. 
A

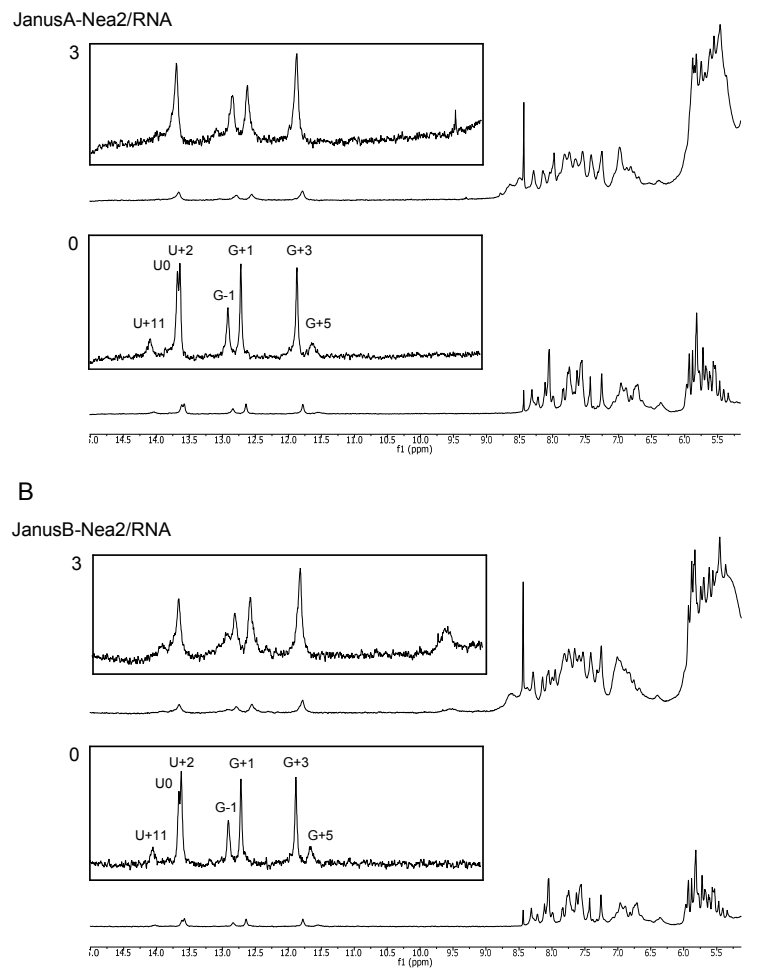

Figure 3. Region of the NMR spectra of wt RNA alone and in the presence of 3 mol equiv. of JanusA-Nea2 (A) or JanusB-Nea2 (B) ligands. Imino proton signals are labelled according to the numbering scheme shown in Figure 1. Assignments were taken from Varani et al. ${ }^{12 \mathrm{a}, 13 \mathrm{c}}$ The RNA concentration was $40 \mu \mathrm{M}$ in a $10 \mathrm{mM}$ sodium phosphate buffer, $\mathrm{pH} 6.8$, in a $90 \% / 10 \% \mathrm{H}_{2} \mathrm{O} / \mathrm{D}_{2} \mathrm{O}$ mixture $\left(\mathrm{T}=5^{\circ} \mathrm{C}\right)$. 


\section{CONCLUSION}

In summary, two Janus-type heterocycles with capacity to recognize guanine and uracyl in G-U mismatched pairs through complementary hydrogen bond pairing have been described. The key step in the synthesis of Janus A monomer (11 steps, $68 \%$ average stepwise yield) involved the use of trichloroacetyl isocyanate, that allowed cyclization of the intermediate to generate both fused faces. In the case of Janus B monomer (4 steps, $47 \%$ average stepwise yield), condensation of 5-cyanocytosine and dicyandiamine under energetic conditions was necessary to generate the diaminotriazine ring. Both compounds were conveniently derivatized with a cysteine-containing tripeptide by using solid-phase methodologies. Thiol-disulfide exchange reactions on a solution phase were used for the assembly of Janus-Neamine ligands differing in the length of the spacer linking the Janus moiety and the aminoglycoside. Their guanidinylated derivatives, Janus-Guanidinoneamine ligands, were also prepared directly by guanidinylation of their amino parent compounds. All Janus-containing ligands were able to stabilize two mutated sequences associated with the development of FTDP-17, particularly the +3 . Moreover, ligands containing JanusB fragment bind with high affinity $\left(\mathrm{EC}_{50}=120-300 \mathrm{nM}\right)$ this RNA sequence, showing a good correlation between binding affinity ant their stabilizing properties. Although no evidence of the formation of hydrogen bonds between the Janus heterocycles and wt RNA can be deduced from $1 \mathrm{D}{ }^{1} \mathrm{H}$ NMR titration experiments, changes in some chemical shifts confirm binding to this target. Efforts are underway to study by NMR spectroscopy the structure of the +3 mutated RNA sequence and their complexes with Janus-containing ligands to determine if the higher stabilizing ability of these compounds with respect this RNA target is related with the recognition of G-U mismatched pairs by Janus heterocycles. Furthermore, these Janus-type building blocks might be used in the future to develop specific ligands for targeting G-U pairs in other human disease-causing RNAs. 


\section{EXPERIMENTAL SECTION}

Unless otherwise stated, common chemicals and solvents (HPLC grade or reagent grade quality) were purchased from commercial sources and used without further purification. Aluminium plates coated with a $0.2 \mathrm{~mm}$ thick layer of silica gel $60 \mathrm{~F}_{254}$ were used for thinlayer chromatography analyses (TLC), whereas flash column chromatography purification was carried out using silica gel 60 (230-400 mesh). Reversed-phase high-performance liquid chromatography (HPLC) analyses of the compounds were carried out on a Jupiter Proteo $\mathrm{C}_{18}$ column $(250 \times 4.6 \mathrm{~mm}, 90 \AA 4 \mu \mathrm{m}$, flow rate: $1 \mathrm{~mL} / \mathrm{min})$ using linear gradients of $0.045 \%$ TFA in $\mathrm{H}_{2} \mathrm{O}$ (solvent A) and $0.036 \%$ TFA in ACN (solvent B). Semipreparative purification was carried out in a Jupiter Proteo column $(250 \times 10 \mathrm{~mm}, 10 \mu \mathrm{m}$, flow rate: 3 $\mathrm{mL} / \mathrm{min}$ ), using linear gradients of $0.1 \%$ TFA in $\mathrm{H}_{2} \mathrm{O}$ (solvent $\mathrm{A}$ ) and $0.1 \%$ TFA in ACN (solvent B). After several runs, pure fractions were combined and lyophilized. NMR spectra were recorded at $25^{\circ} \mathrm{C}$ on different spectrometers $(300,400,500$ or $600 \mathrm{MHz})$ using deuterated solvents. Tetramethylsilane (TMS) was used as an internal reference (0 ppm) for ${ }^{1} \mathrm{H}$ spectra recorded in $\mathrm{CDCl}_{3}$ and the residual signal of the solvent (77.16 ppm) for ${ }^{13} \mathrm{C}$ spectra. For DMSO- $d_{6}$, the residual signal of the solvent was used as a reference in ${ }^{1} \mathrm{H}$ and ${ }^{13} \mathrm{C}$ spectra. Chemical shifts are reported in part per million (ppm) in the $\delta$ scale, coupling constants in $\mathrm{Hz}$ and multiplicity as follows: $\mathrm{s}$ (singlet), $\mathrm{d}$ (doublet), $\mathrm{t}$ (triplet), $\mathrm{q}$ (quadruplet), qt (quintuplet), m (multiplet), td (doublet of triplets), br (broad signal). Electrospray ionization mass spectra (ESI-MS) were recorded on an instrument equipped with single quadrupole detector coupled to an HPLC, and high-resolution (HR) ESI-MS on a LC/MS-TOF instrument.

\section{Synthesis of Janus A monomer (1).}

2,4,6-trichloropyrimidine-5-carbaldehyde (3). Barbituric acid (30 g, $0.234 \mathrm{~mol}$ ) was slowly added to a stirred solution of $\mathrm{POCl}_{3}(140 \mathrm{~mL}, 1.51 \mathrm{~mol})$ in DMF $(25 \mathrm{~mL}, 0.234$ mol) at room temperature under Ar, which rapidly acquired a yellow colour. After refluxing for $15 \mathrm{~h}$, the mixture was allowed to cool down to room temperature and evaporated in vacuo to remove most of $\mathrm{POCl}_{3}$ excess. Then, the residue was carefully poured over crushed ice while maintaining vigorous stirring, and the resulting brown precipitate was filtered and dried under vacuum. After flash column chromatography (gradient: 0-50\% AcOEt in hexane), the desired product was obtained as a brown solid $(21 \mathrm{~g}, 42 \%)$ and used 
in the next step without further purification. TLC: $\mathrm{R}_{\mathrm{f}}(10 \% \mathrm{AcOEt} / \mathrm{Hexane}): 0.43 ; \mathrm{m} . \mathrm{p}$ : 166-169 ${ }^{\circ} \mathrm{C} ;{ }^{1} \mathrm{H}$ NMR $\left(400 \mathrm{MHz}, C D C l_{3}\right) \delta(\mathrm{ppm}): 10.42(1 \mathrm{H}, \mathrm{s}) ;{ }^{13} \mathrm{C} \mathrm{NMR}(100 \mathrm{MHz}$, $\left.\mathrm{CDCl}_{3}\right) \delta(\mathrm{ppm}): 184.8,164.2,161.8,123.2$.

Ethyl 4-((2,6-dichloro-5-formylpyrimidin-4-yl)amino)butanoate (4a). To a stirred solution of $\mathbf{3}(10 \mathrm{~g}, 47.3 \mathrm{mmol})$ in DCM (200 mL), a solution of ethyl 4-aminobutyrate hydrochloride (7.92 g, $47.3 \mathrm{mmol})$ and DIPEA (16.1 mL, $94.6 \mathrm{mmol})$ in DCM (100 mL) was slowly added at $-78^{\circ} \mathrm{C}$ under Ar atmosphere. The resulting mixture, which immediately acquired a yellow colour, was stirred at $-78^{\circ} \mathrm{C}$ for $6 \mathrm{~h}$. Once at $\mathrm{rt}$, the reaction mixture was taken up and washed with water $(2 \times 50 \mathrm{~mL})$ and brine $(50 \mathrm{~mL})$. The resulting organic phase was dried over anhydrous $\mathrm{MgSO}_{4}$, filtered and concentrated in vacuo to dryness. After flash column chromatography (gradient: 2.5-20\% AcOEt in hexane), the desired compound (4a) was obtained as a yellow crystalline solid (8.53 g, 60\%). In addition, regioisomer $\mathbf{4 b}$ was also isolated as a minor product. Data for $4 \mathbf{a}$ : TLC: $\mathrm{R}_{\mathrm{f}}(20 \%$ AcOEt/Hexane): 0.37; m.p: 91-93 ${ }^{\circ} \mathrm{C} ;{ }^{1} \mathrm{H}$ NMR (300 MHz, $\left.C D C l_{3}\right) \delta(\mathrm{ppm}): 10.3(1 \mathrm{H}, \mathrm{s})$, $9.36(1 \mathrm{H}, \mathrm{br} \mathrm{s}), 4.15(2 \mathrm{H}, \mathrm{q}, J=7.2 \mathrm{~Hz}), 3.67(2 \mathrm{H}, \mathrm{dt}, J=6.9 \mathrm{~Hz}), 2.40(2 \mathrm{H}, \mathrm{t}, J=7.2 \mathrm{~Hz})$, $1.99(2 \mathrm{H}, \mathrm{qt}, J=7.2 \mathrm{~Hz}), 1.27(3 \mathrm{H}, \mathrm{t}, J=7.2 \mathrm{~Hz}) ;{ }^{13} \mathrm{C} \mathrm{NMR}\left(75 \mathrm{MHz}, C D C l_{3}\right) \delta(\mathrm{ppm})$ : 190.7, 172.8, 166.3 163.0, 162.1, 106.9, 60.9, 40.8, 31.6, 24.5, 14.4; HRMS (ESI, positive mode): $m / z 306.0410[\mathrm{M}+\mathrm{H}]^{+}$(calcd mass for $\mathrm{C}_{11} \mathrm{H}_{14} \mathrm{Cl}_{2} \mathrm{~N}_{3} \mathrm{O}_{3}[\mathrm{M}+\mathrm{H}]^{+}:$306.0412). Data for 4b: TLC: $\mathrm{R}_{\mathrm{f}}\left(20 \%\right.$ AcOEt/Hexane): 0.24; ${ }^{1} \mathrm{H}$ NMR (300 MHz, $\left.C D C l_{3}\right) \delta(\mathrm{ppm}): 10.25(1 \mathrm{H}$, s), $6.27(1 \mathrm{H}$, br s), $4.15(2 \mathrm{H}, \mathrm{q}, J=7.2 \mathrm{~Hz}), 3.59(2 \mathrm{H}, \mathrm{dt}, J=6.9 \mathrm{~Hz}), 2.41(2 \mathrm{H}, \mathrm{t}, J=7.2$ $\mathrm{Hz}), 1.99(2 \mathrm{H}, \mathrm{qt}, J=7.2 \mathrm{~Hz}), 1.27(3 \mathrm{H}, \mathrm{t}, J=7.2 \mathrm{~Hz}) ;{ }^{13} \mathrm{C} \mathrm{NMR}\left(75 \mathrm{MHz}, \mathrm{CDCl}_{3}\right) \delta$ (ppm): 185.0, 173.1, 165.2, 163.9, 160.5, 114.4, 60.9, 41.5, 31.6, 24.4, 14.4; MS (ESI, positive mode): $m / z 306.3[\mathrm{M}+\mathrm{H}]^{+}$(calcd mass for $\mathrm{C}_{11} \mathrm{H}_{14} \mathrm{Cl}_{2} \mathrm{~N}_{3} \mathrm{O}_{3}[\mathrm{M}+\mathrm{H}]^{+}:$306.0412).

Ethyl 4-((2-amino-6-chloro-5-formylpyrimidin-4-yl)amino)butanoate (5). To a stirred solution of $4 \mathbf{a}(8.33 \mathrm{~g}, 27.3 \mathrm{mmol})$ in absolute ethanol $(250 \mathrm{~mL}), 55 \mathrm{~mL}(819 \mathrm{mmol})$ of a $3: 7(\mathrm{v} / \mathrm{v})$ mixture of $\mathrm{NH}_{4} \mathrm{OH} 32 \%(\mathrm{w} / \mathrm{w})$ and $\mathrm{EtOH}$ were added at room temperature. After stirring for $5 \mathrm{~h}$ at $\mathrm{rt}$, the reaction mixture was evaporated to dryness. The residue was dissolved in AcOEt $(100 \mathrm{~mL})$ and washed with water $(2 \times 50 \mathrm{~mL})$ and brine $(50 \mathrm{~mL})$. The organic phase was taken up, dried over anhydrous $\mathrm{MgSO}_{4}$, filtered and concentrated in vacuo to dryness, providing the desired product as a yellow solid (7.84 g, quantitative yield), which was used without futher purification in the next step. TLC: $\mathrm{R}_{\mathrm{f}}(50 \%$ AcOEt/Hexane): 0.57; ${ }^{1} \mathrm{H}$ NMR (400 MHz, $\left.C D C l_{3}\right) \delta$ ppm: $10.08(1 \mathrm{H}, \mathrm{s}), 9.27(1 \mathrm{H}, \mathrm{br} \mathrm{s})$, $5.41(2 \mathrm{H}, \mathrm{br} \mathrm{s}), 4.14(2 \mathrm{H}, \mathrm{q}, J=7.2 \mathrm{~Hz}), 3.55(2 \mathrm{H}, \mathrm{dt}, J=6.9 \mathrm{~Hz}), 2.38(2 \mathrm{H}, \mathrm{t}, J=7.2 \mathrm{~Hz})$, 
$1.95(2 \mathrm{H}, \mathrm{qt}, J=7.2 \mathrm{~Hz}), 1.26(3 \mathrm{H}, \mathrm{t}, J=7.2 \mathrm{~Hz}) ;{ }^{13} \mathrm{C} \mathrm{NMR}\left(100 \mathrm{MHz}, C D C l_{3}\right) \delta \mathrm{ppm}:$ 188.9, 173.1, 166.7, 162.9, 162.4, 102.7, 60.7, 39.9, 31.7, 24.7, 14.3; HRMS (ESI, positive mode): $m / z 287.0911[\mathrm{M}+\mathrm{H}]^{+}$(calcd mass for $\mathrm{C}_{11} \mathrm{H}_{16} \mathrm{ClN}_{4} \mathrm{O}_{3}[\mathrm{M}+\mathrm{H}]^{+}$: 287.0911).

Ethyl 4-((2-amino-5-formylpyrimidin-4-yl)amino)butanoate (6). To a stirred solution of 5 (7.80 g, $27.21 \mathrm{mmol})$ and NaOAc (4.35 g, $108.8 \mathrm{mmol})$ in absolute EtOH $(250 \mathrm{~mL}), 10 \%$ $\mathrm{Pd} / \mathrm{C}$ (521 mg, $0.49 \mathrm{mmol})$ was added under Ar atmosphere. The reaction mixture was stirred at $\mathrm{rt}$ under atmospheric pressure of $\mathrm{H}_{2}$ for $15 \mathrm{~h}$. On the basis of TLC analysis, additional $10 \% \mathrm{Pd} / \mathrm{C}(1 \mathrm{mmol})$ and $\mathrm{NaOAc}(54.42 \mathrm{mmol})$ were required for the reaction to reach completion within $6 \mathrm{~h}$. The reaction mixture was filtered through Celite (previously washed with $\mathrm{EtOH})$, and the product was eluted with $\mathrm{EtOH}(50 \mathrm{~mL})$ and $\mathrm{MeOH}(4 \times 50$ $\mathrm{mL}$ ). The combined filtrates were collected together and evaporated in vacuo affording a slightly yellow solid. After flash column chromatography (gradient: AcOEt/hexane (1:1)$100 \%$ AcOEt-2\% MeOH/AcOEt) the desired compound (6) was obtained as a white solid (3.87 g, 56\%). TLC: $\mathrm{R}_{\mathrm{f}}(\mathrm{AcOEt}): 0.28 ;{ }^{1} \mathrm{H} \mathrm{NMR}\left(400 \mathrm{MHz}, C D C l_{3}\right) \delta \mathrm{ppm}: 9.50(1 \mathrm{H}, \mathrm{s})$, $8.63(1 \mathrm{H}, \mathrm{br} \mathrm{s}), 8.15(1 \mathrm{H}, \mathrm{s}), 4.14(2 \mathrm{H}, \mathrm{q}, J=7.2 \mathrm{~Hz}), 3.54(2 \mathrm{H}, \mathrm{dt}, J=6.8 \mathrm{~Hz}), 2.39(2 \mathrm{H}, \mathrm{t}$, $J=7.2 \mathrm{~Hz}), 1.96(2 \mathrm{H}, \mathrm{qt}, J=7.2 \mathrm{~Hz}), 1.26(3 \mathrm{H}, \mathrm{t}, J=7 . \mathrm{Hz}) ;{ }^{13} \mathrm{C} \mathrm{NMR}\left(100 \mathrm{MHz}, C \mathrm{CCl}_{3}\right)$ $\delta$ ppm: 189.2, 173.1, 166.1, 163.8, 161.8, 107.2, 60.6, 39.3, 31.8, 24.8, 14.4; HRMS (ESI, positive mode): $m / z 253.1298[\mathrm{M}+\mathrm{H}]^{+}$(calcd mass for $\mathrm{C}_{11} \mathrm{H}_{17} \mathrm{~N}_{4} \mathrm{O}_{3}[\mathrm{M}+\mathrm{H}]^{+}:$253.1301).

\section{Ethyl 4-((2-bis(tert-butoxycarbonyl)amino-5-formylpyrimidin-4-yl)amino)butanoate}

(7). Compound 6 (3.87 g, $15.34 \mathrm{mmol})$ was dissolved in anhydrous DCM (100 mL) under Ar. Then, anhydrous triethylamine (10.2 ml, $67.5 \mathrm{mmol})$, DMAP $(187 \mathrm{mg}, 1.53 \mathrm{mmol})$ and $\mathrm{Boc}_{2} \mathrm{O}(7.4 \mathrm{~g}, 33.75 \mathrm{mmol})$ were added sequentially. After stirring under Ar for $18 \mathrm{~h}$, the reaction mixture was evaporated in vacuo. The residue was dissolved in AcOEt (100 mL) and washed with $10 \%$ citric acid $(50 \mathrm{~mL}), 10 \% \mathrm{NaHCO}_{3}(125 \mathrm{~mL})$, and brine $(50 \mathrm{~mL})$. The organic phase was taken up, dried over anhydrous $\mathrm{MgSO}_{4}$, filtered and concentrated in vacuo to dryness. After flash column chromatography (gradient: 0-50\% AcOEt in hexane), the desired compound (7) was obtained as a white solid (4.1 g, 29.3\%). TLC: $\mathrm{R}_{\mathrm{f}}(\mathrm{AcOEt})$ : 0.84; m.p: $163-173^{\circ} \mathrm{C} ;{ }^{1} \mathrm{H}$ NMR (400 MHz, $\left.C D C l_{3}\right) \delta$ (ppm): $9.77(1 \mathrm{H}, \mathrm{s}), 8.65(1 \mathrm{H}$, br t), $8.52(1 \mathrm{H}, \mathrm{s}), 4.14(2 \mathrm{H}, \mathrm{d}, J=7.2 \mathrm{~Hz}), 3.58(2 \mathrm{H}, \mathrm{q}, J=6.8 \mathrm{~Hz}), 2.37(2 \mathrm{H}, \mathrm{t}, J=7.2 \mathrm{~Hz})$, $1.97(2 \mathrm{H}, \mathrm{qt}, J=7.2 \mathrm{~Hz}), 1.53(18 \mathrm{H}, \mathrm{s}), 1.26(3 \mathrm{H}, \mathrm{t}, J=7.2 \mathrm{~Hz}) ;{ }^{13} \mathrm{C} \mathrm{NMR}(100 \mathrm{MHz}$, $\left.\mathrm{CDCl}_{3}\right) \delta(\mathrm{ppm}): 190.8,172.9,165.3,161.3,160.3,150.4,110.3,83.9,60.7,39.9,31.7$, 27.9, 24.6, 14.3; HRMS (ESI, positive mode): $m / z 453.2352[\mathrm{M}+\mathrm{H}]^{+}$(calcd mass for $\mathrm{C}_{21} \mathrm{H}_{33} \mathrm{~N}_{4} \mathrm{O}_{7}[\mathrm{M}+\mathrm{H}]^{+}:$453.2349). 


\section{Ethyl 4-((2-bis(tert-butoxycarbonyl)amino-5-((hydroxyimino)methyl)pyrimidin-4-}

yl)amino)butanoate (8). To a solution of compound $7(4.22 \mathrm{~g}, 9.33 \mathrm{mmol})$ in pyridine (100 $\mathrm{mL})$, hydroxylamine hydrochloride $(1.3 \mathrm{~g}, 18.7 \mathrm{mmol})$ was added and the mixture was stirred under Ar for $6 \mathrm{~h}$. The solvent was evaporated in vacuo and after several coevaporations from toluene, the residue was dissolved in AcOEt $(100 \mathrm{~mL})$. The organic phase was washed with water $(50 \mathrm{~mL})$ and brine $(50 \mathrm{~mL})$, dried over anhydrous $\mathrm{MgSO}_{4}$, filtered and concentrated in vacuo to dryness. The desired compound (8) was obtained as a yellow solid (3.85 g, 88\%) and used in the next step without further purification. TLC: $\mathrm{R}_{\mathrm{f}}$ (AcOEt): 0.84; IR (KBr): $v=3337.8,1798.5,1729.6,1616.1,1587.1 \mathrm{~cm}^{-1} ;{ }^{1} \mathrm{H}$ NMR (400 $\left.\mathrm{MHz}, \mathrm{CDCl}_{3}\right) \delta(\mathrm{ppm}): 8.13(1 \mathrm{H}, \mathrm{s}) 8.13(1 \mathrm{H}, \mathrm{s}), 8.05(1 \mathrm{H}, \mathrm{br} \mathrm{s}), 8.00(1 \mathrm{H}, \mathrm{br} \mathrm{s}), 4.12(2 \mathrm{H}$, q, $J=7.2 \mathrm{~Hz}), 3.58(2 \mathrm{H}, \mathrm{dt}, J=6.8 \mathrm{~Hz}), 2.37(2 \mathrm{H}, \mathrm{t}, J=7.2 \mathrm{~Hz}), 1.96(2 \mathrm{H}, \mathrm{qt}, J=7.2 \mathrm{~Hz})$, $1.48(18 \mathrm{H}, \mathrm{s}), 1.24(3 \mathrm{H}, \mathrm{t}, J=7.2 \mathrm{~Hz}) ;{ }^{13} \mathrm{C} \mathrm{NMR}\left(100 \mathrm{MHz}, C D C l_{3}\right) \delta(\mathrm{ppm}): 173.3,160.1$, 157.7, 157.2, 150.9, 147.9, 107.2, 83.2, 60.6, 40.1, 31.8, 28.0, 24.8, 14.3; HRMS (ESI, positive mode): $m / z 468.2454[\mathrm{M}+\mathrm{H}]^{+}$(calcd mass for $\mathrm{C}_{21} \mathrm{H}_{34} \mathrm{~N}_{5} \mathrm{O}_{7}[\mathrm{M}+\mathrm{H}]^{+}: 468.2458$ ).

\section{Ethyl 4-((2-bis(tert-butoxycarbonyl)amino-5-cyanopyrimidin-4-yl)amino)butanoate}

(9). To a solution of compound 8 (3.85 g, $8.24 \mathrm{mmol})$ in anhydrous THF (100 mL), triethylamine $(3.7 \mathrm{~mL}, 24.72 \mathrm{mmol})$ was added under Ar. Then, the solution was cooled to $0^{\circ} \mathrm{C}$ and trifluoroacetic anhydride $(1.7 \mathrm{ml}, 12.36 \mathrm{mmol})$ was added slowly while stirring. The mixture was allowed to warm and stirred for $2 \mathrm{~h}$ at $\mathrm{rt}$. The mixture was cooled back to $0^{\circ} \mathrm{C}$, and cold water $(2 \mathrm{~mL})$ was added to destroy the excess of TFAA, and the solvent was evaporated in vacuo. The residue was dissolved in AcOEt $(50 \mathrm{~mL})$, washed with $10 \%$ citric acid $(25 \mathrm{~mL}), 10 \% \mathrm{NaHCO}_{3}(25 \mathrm{~mL})$ and brine $(25 \mathrm{~mL})$. The organic phase was taken up, dried over anhydrous $\mathrm{MgSO}_{4}$, filtered and evaporated in vacuo. The desired compound (9) was obtained after flash column chromatography (gradient: 0-25\% AcOEt in hexane) as a white solid (2.94 g, 79\%). TLC: $\mathrm{R}_{\mathrm{f}}$ (25\% AcOEt in Hexane): 0.44; m.p: 189-193 ${ }^{\circ} \mathrm{C}$; IR $(\mathrm{KBr}): \mathrm{v}=3322.8,2222.7,1787.9,1734.5,1598,1580.7 \mathrm{~cm}^{-1} ;{ }^{1} \mathrm{H}$ NMR $\left(400 \mathrm{MHz}, \mathrm{CDCl}_{3}\right)$ $\delta$ (ppm): $8.42(1 \mathrm{H}, \mathrm{s}), 6.12(1 \mathrm{H}, \mathrm{brt}, J=5.4 \mathrm{~Hz}), 4.16(2 \mathrm{H}, \mathrm{q}, J=7.2 \mathrm{~Hz}), 3.57(2 \mathrm{H}, \mathrm{dt}, J=$ $6.8 \mathrm{~Hz}), 2.40(2 \mathrm{H}, \mathrm{t}, J=7.2 \mathrm{~Hz}), 1.97(2 \mathrm{H}, \mathrm{qt}, J=7.2 \mathrm{~Hz}), 1.51(18 \mathrm{H}, \mathrm{s}), 1.27(3 \mathrm{H}, \mathrm{t}, J$ $=7.2 \mathrm{~Hz}) ;{ }^{13} \mathrm{C} \mathrm{NMR}\left(100 \mathrm{MHz}, \mathrm{CDCl}_{3}\right) \delta \mathrm{ppm}: 173.4,162.4,161.2,159.6,150.3,114.9$, 88.6, 84.1, 61.0, 41.0, 31.8, 29.9, 24.2, 14.4; HRMS (positive mode): $m / z 450.2352[\mathrm{M}+\mathrm{H}]^{+}$ (calcd mass for $\mathrm{C}_{21} \mathrm{H}_{32} \mathrm{~N}_{5} \mathrm{O}_{6}[\mathrm{M}+\mathrm{H}]^{+}$: 450.2353). 


\section{Ethyl 4-(1-(2-bis(tert-butoxycarbonyl)amino-5-cyanopyrimidin-4-yl)-3-(2,2,2-}

trichloroacetyl)ureido)butanoate (10). To a solution of compound $9(1 \mathrm{~g}, 0.636 \mathrm{mmol})$ in anhydrous DCM $(5 \mathrm{~mL})$, a solution of trichloroacetyl isocyanate $(0.78 \mathrm{~mL}, 6.36 \mathrm{mmol})$ in anhydrous DCM $(9 \mathrm{~mL})$ was added dropwise at $0^{\circ} \mathrm{C}$ over a period of 10 min under $\mathrm{Ar}$ atmosphere. After stirring for $1 \mathrm{~h}$ at $0^{\circ} \mathrm{C}$, the reaction mixture was allowed to warm to $\mathrm{rt}$ and stirred for an additional $5 \mathrm{~h}$. The reaction mixture was cooled to $0^{\circ} \mathrm{C}$ and quenched with cold water $(25 \mathrm{~mL})$. The organic phase was taken up, washed with water $(3 \times 15 \mathrm{~mL})$, dried over anhydrous $\mathrm{MgSO}_{4}$, filtered and evaporated in vacuo. The desired compound (10) was obtained after flash column chromatography (gradient: 0-50\% AcOEt in hexane) as a yellow solid (1.92 g, quantitative). TLC: $\mathrm{R}_{\mathrm{f}}(\mathrm{AcOEt}): 0.93$; m.p: $134-137^{\circ} \mathrm{C}$; ${ }^{1} \mathrm{H}$ NMR (400 $\left.\mathrm{MHz}, \mathrm{CDCl}_{3}\right) \delta(\mathrm{ppm}): 9.53(1 \mathrm{H}, \mathrm{s}), 4.32(2 \mathrm{H}, J=6.8 \mathrm{~Hz}), 4.12(2 \mathrm{H}, \mathrm{q}, J=7.2 \mathrm{~Hz}), 2.41$ $(2 \mathrm{H}, \mathrm{t}, J=7.2 \mathrm{~Hz}), 2.10(2 \mathrm{H}, \mathrm{qt}, J=7.2 \mathrm{~Hz}), 1.57(18 \mathrm{H}, \mathrm{s}), 1.24(3 \mathrm{H}, \mathrm{t}, J=7.2 \mathrm{~Hz}) ;{ }^{13} \mathrm{C}$ NMR (100 MHz, $\left.\mathrm{CDCl}_{3}\right) \delta(\mathrm{ppm}):$ 174.0, 172.7, 163.9, 160.8, 159.1, 158.2, 149.5, 147.5 104.6, 92.0, 85.1, 60.8, 42.1, 31.6, 27.9, 22.9, 14.3; HRMS (ESI, positive mode): $\mathrm{m} / \mathrm{z}$ $637.1336[\mathrm{M}+\mathrm{H}]^{+}$(calcd mass for $\mathrm{C}_{24} \mathrm{H}_{32} \mathrm{Cl}_{3} \mathrm{~N}_{6} \mathrm{O}_{8}[\mathrm{M}+\mathrm{H}]^{+}$: 637.1342).

\section{Ethyl 4-(4-amino-7-(bis(tert-butoxycarbonyl)amino)-2-oxopyrimido[4,5-d]pyrimidin-} 1(2H)-yl)butanoate (11). Compound 10 (1.42 g, $2.23 \mathrm{mmol})$ was stirred in $7 \mathrm{~N} \mathrm{NH}_{3}$ in $\mathrm{MeOH}(50 \mathrm{~mL})$ under Ar atmosphere at $-10^{\circ} \mathrm{C}$ (ice- $\mathrm{NaCl}$ bath) for $2 \mathrm{~h}$. After evaporation in vacuo, the resulting solid was dissolved in DCM $(30 \mathrm{~mL})$. The organic phase was washed with water $(3 \times 25 \mathrm{~mL})$, dried over anhydrous $\mathrm{MgSO}_{4}$, filtered and evaporated in vacuo. The desired compound (11) was obtained as a yellow solid (878 $\mathrm{mg}, 80.1 \%)$ and used without further purification in the next step. TLC: $\mathrm{R}_{\mathrm{f}}(15 \% \mathrm{MeOH} / \mathrm{AcOEt}): 0.68$; IR $(\mathrm{NaCl}): v=3400,1738.8,1652.6,1635.5,1602.3,1558.9,1540 \mathrm{~cm}^{-1} ;{ }^{1} \mathrm{H}$ NMR $(400 \mathrm{MHz}$, $\left.C \mathrm{Cl}_{3}\right) \delta(\mathrm{ppm}): 9.28(1 \mathrm{H}, \mathrm{s}), 4.27(2 \mathrm{H}, \mathrm{t}, J=7.2 \mathrm{~Hz}), 4.10(2 \mathrm{H}, \mathrm{q}, J=7.2 \mathrm{~Hz}), 2.38(2 \mathrm{H}, \mathrm{t}$, $J=7.6 \mathrm{~Hz}), 2.05(2 \mathrm{H}, \mathrm{qt}, J=7.6 \mathrm{~Hz}), 1.53(18 \mathrm{H}, \mathrm{s}), 1.22(3 \mathrm{H}, \mathrm{t}, J=7.2 \mathrm{~Hz}) ;{ }^{13} \mathrm{C} \mathrm{NMR}$ $\left(100 \mathrm{MHz}, \mathrm{CDCl}_{3}\right) \delta(\mathrm{ppm}): 173.0,161.4,160.4,158.7,156.8,155.9,150.2,101.1,84.5$, 60.6, 41.4, 31.8, 27.9, 23.3, 14.3; HRMS (ESI, positive mode): $m / z 493.2411[\mathrm{M}+\mathrm{H}]^{+}$ (calcd mass for $\mathrm{C}_{22} \mathrm{H}_{33} \mathrm{~N}_{6} \mathrm{O}_{7}[\mathrm{M}+\mathrm{H}]^{+}$: 493.2405).

\section{Ethyl 4-(7-(bis(tert-butoxycarbonyl)amino)-4-((tert-butoxycarbonyl)amino)-2-} oxopyrimido[4,5-d]pyrimidin-1(2H)-yl)butanoate (12). To a solution of compound 11 $(878 \mathrm{mg}, 2.23 \mathrm{mmol})$ in anhydrous DCM $(30 \mathrm{~mL})$, anhydrous triethylamine $(1.62 \mathrm{~mL}$, $13.38 \mathrm{mmol})$, DMAP (218 mg, $2.23 \mathrm{mmol})$ and $\mathrm{Boc}_{2} \mathrm{O}(1.17 \mathrm{~g}, 6.69 \mathrm{mmol})$ were added under Ar atmosphere. After stirring for $24 \mathrm{~h}$ at $\mathrm{rt}$, the colour changed from yellow to brown. 
The reaction mixture was taken up and the organic phase was washed with water $(2 \times 25$ mL) $10 \%$ citric acid $(25 \mathrm{~mL}), 10 \% \mathrm{NaHCO}_{3}(25 \mathrm{~mL})$ and brine $(25 \mathrm{~mL})$, then dried over anhydrous $\mathrm{MgSO}_{4}$ and filtered. After removal of the solvent under reduced pressure, compound 12 was obtained as a brown solid $(1.11 \mathrm{~g}, 90 \%)$, which was used without further purification in the next step. TLC: $\mathrm{R}_{\mathrm{f}}(50 \% \mathrm{AcOEt} / \mathrm{Hexane}): 0.78 ;{ }^{1} \mathrm{H}$ NMR (400 MHz, $\left.C D l_{3}\right) \delta(\mathrm{ppm}): 9.42(1 \mathrm{H}, \mathrm{s}), 4.24(2 \mathrm{H}, \mathrm{t}, J=7.2 \mathrm{~Hz}), 4.09(2 \mathrm{H}, \mathrm{q}, J=7.2 \mathrm{~Hz}), 2.37(2 \mathrm{H}, \mathrm{t}$, $J=7.2 \mathrm{~Hz}), 2.04(2 \mathrm{H}, \mathrm{qt}, J=7.2 \mathrm{~Hz}), 1.54(18 \mathrm{H}, \mathrm{s}), 1.50(9 \mathrm{H}, \mathrm{s}), 1.22(3 \mathrm{H}, \mathrm{t}, J=7.2 \mathrm{~Hz})$; ${ }^{13} \mathrm{C}$ NMR (100 MHz, $\left.\mathrm{CDCl}_{3}\right) \delta(\mathrm{ppm}):$ 172.6, 161.2, 159.3, 158.0, 157.9, 155.6, 149.9, 148.2 105.6, 84.9, 84.5, 60.7, 41.5, 31.6, 28.1, 27.9, 23.1, 14.3; HRMS (ESI, positive mode): $m / z 593.2937[\mathrm{M}+\mathrm{H}]^{+}$(calcd mass for $\mathrm{C}_{27} \mathrm{H}_{41} \mathrm{~N}_{6} \mathrm{O}_{9}[\mathrm{M}+\mathrm{H}]^{+}:$593.2930).

\section{4-(7-(Bis(tert-butoxycarbonyl)amino)-4-((tert-butoxycarbonyl)amino)-2-}

oxopyrimido[4,5-d]pyrimidin-1(2H)-yl)butanoic acid (1). To a solution of 12 (550 mg, $0.325 \mathrm{mmol})$ in a $3: 1(\mathrm{v} / \mathrm{v})$ mixture of $\mathrm{H}_{2} \mathrm{O} / \mathrm{ACN}(30 \mathrm{~mL})$, a solution of $\mathrm{LiOH}(400 \mathrm{mg}$, $3.25 \mathrm{mmol})$ in water $(1 \mathrm{~mL})$ was added. After stirring for $1 \mathrm{~h}$ at $\mathrm{rt}$, the reaction mixture was concentrated in vacuo to remove ACN. The resulting aqueous phase was acidified with $10 \%$ citric acid to $\mathrm{pH} 3-4$, causing the precipitation of a white solid, which was re-dissolved with AcOEt $(10 \mathrm{~mL})$. The organic phase was taken up and the aqueous phase was washed with AcOEt $(2 \times 10 \mathrm{~mL})$. The combined organic phases were dried over anhydrous $\mathrm{MgSO}_{4}$, filtered and evaporated in vacuo. The desired compound (1) was obtained after flash column chromatography (gradient: $50-100 \%$ AcOEt in hexane, $100 \%$ AcOEt- $15 \% \mathrm{MeOH}$ in AcOEt) as a yellow solid (130 mg, 27.3\%). TLC: $\mathrm{R}_{\mathrm{f}}(\mathrm{AcOEt}): 0.80 ; \mathrm{m} . \mathrm{p}: 190-193^{\circ} \mathrm{C}$; IR $(\mathrm{KBr}): \mathrm{v}=3362.5,1764.3,1751.3,1728.6,1661.5,1602.3 \mathrm{~cm}^{-1} ;{ }^{1} \mathrm{H}$ NMR $(400 \mathrm{MHz}$, $\left.\mathrm{CDCl}_{3}\right) \delta(\mathrm{ppm}): 12.10(1 \mathrm{H}, \mathrm{br} \mathrm{s}), 9.43(1 \mathrm{H}, \mathrm{s}), 4.28(2 \mathrm{H}, \mathrm{t}, J=6.8 \mathrm{~Hz}), 2.44(2 \mathrm{H}, \mathrm{t}, J=7.2$ $\mathrm{Hz}), 2.07(2 \mathrm{H}, \mathrm{qt}, J=7.2 \mathrm{~Hz}), 1.57(9 \mathrm{H}, \mathrm{s}), 1.51(18 \mathrm{H}, \mathrm{s}) ;{ }^{13} \mathrm{C} \mathrm{NMR}\left(100 \mathrm{MHz}, \mathrm{CDCl}_{3}\right) \delta$ (ppm): 177.4, 162.6, 161.2, 159.3, 158.0, 155.5, 149.9, 148.1, 105.6, 84.6, 82.1, 41.3, 31.1, 28.1, 27.9, 22.9; HRMS (ESI, positive mode): $m / z 565.2618[\mathrm{M}+\mathrm{H}]^{+}$(calcd mass for $\mathrm{C}_{25} \mathrm{H}_{37} \mathrm{~N}_{6} \mathrm{O}_{9}[\mathrm{M}+\mathrm{H}]^{+}:$565.2617).

\section{Synthesis of Janus B monomer (2).}

5-(4,6-Diamino-1,3,5-triazin-2-yl)cytosine (15). To a suspension of compound 14 (5 g, $36.8 \mathrm{mmol})$ in ethylene glycol $(100 \mathrm{~mL})$, a solution of $\mathrm{KOH}(4.1 \mathrm{~g}, 73.5 \mathrm{mmol})$ and dicyandiamide $(6.18 \mathrm{~g}, 73.5 \mathrm{mmol})$ in ethylene glycol $(100 \mathrm{~mL})$ was added dropwise under Ar atmosphere over a period of $10 \mathrm{~min}$. The resulting red-brown solution was refluxed at 
$150^{\circ} \mathrm{C}$ for $40 \mathrm{~h}$. After evaporation in vacuo, the resulting brown solid was washed with water, diethyl ether and EtOH. Finally, compound 15 was obtained as a brown solid (4.53 $\mathrm{g}, 54 \%$ ) and used without further purification in the next step. ${ }^{1} \mathrm{H}$ NMR (400 MHz, DMSO) $\delta$ (ppm): $9.46\left(1 \mathrm{H}\right.$, br s), $8.51(1 \mathrm{H}, \mathrm{s}), 8.01(1 \mathrm{H}$, br s $), 6.81(5 \mathrm{H}, \mathrm{br} \mathrm{s}) ;{ }^{13} \mathrm{C} \mathrm{NMR}(100 \mathrm{MHz}$ DMSO) $\delta(\mathrm{ppm}): 167.9,165.9,164.2,156.0,148.6,99.2$; HRMS (ESI, positive mode): $\mathrm{m} / \mathrm{z}$ $221.0893[\mathrm{M}+\mathrm{H}]^{+}$(calcd mass for $\mathrm{C}_{7} \mathrm{H}_{9} \mathrm{~N}_{8} \mathrm{O}[\mathrm{M}+\mathrm{H}]^{+}: 221.0899$ ).

4-(5-(4,6-Diamino-1,3,5-triazin-2-yl)cytosine-1(2H)-yl)butanoic acid (2). To a solution of compound 15 (630 mg, $2.86 \mathrm{mmol}$ ) in anhydrous DMF, NaH 60\% dispersion in mineral oil (114.4 mg, $2.86 \mathrm{mmol}$ ) was added under Ar atmosphere and the reaction mixture was stirred at $50^{\circ} \mathrm{C}$ for $2 \mathrm{~h}$. Then, ethyl bromobutyrate $(450 \mu \mathrm{L}, 3.15 \mathrm{mmol})$ was slowly added dropwise and the mixture was stirred at $\mathrm{rt}$ for $15 \mathrm{~h}$. After evaporation in vacuo, the residue was dissolved in $30 \% \mathrm{MeOH}$ in $\mathrm{H}_{2} \mathrm{O}(200 \mathrm{~mL})$ at $70^{\circ} \mathrm{C}$, and then allowed to warm to rt. The precipitate was removed by filtration and identified as the starting compound (15). The filtrate was evaporated in vacuo affording a solid that contained ethyl 4-(5-(4,6-diamino1,3,5-triazin-2-yl)cytosine-1(2H)-yl)butanoate (16), as the major component (80\%) according to HPLC-MS analysis. The crude, which was no further purified due to its poor solubility in organic solvents, was dissolved in aqueous $1 \mathrm{M} \mathrm{LiOH}(100 \mathrm{~mL})$ and the brown solution was stirred overnight at $\mathrm{rt}$. Then, $10 \% \mathrm{HCl}$ was added until $\mathrm{pH}=2$. After evaporation in vacuo, purification was accomplished by MPLC eluting with a gradient from 0 to $100 \%$ of B (A: $0.1 \%$ formic acid in $\mathrm{H}_{2} \mathrm{O}$ and $\mathrm{B}: 0.1 \%$ formic acid in $\mathrm{H}_{2} \mathrm{O} / \mathrm{ACN}$ 1:1, 1 L each solvent). Pure fractions by MS-HPLC (linear gradient from 0 to $100 \%$ B in 18 min; A: $0.1 \%$ formic acid in $\mathrm{H}_{2} \mathrm{O}$ and $\mathrm{B}: 0.1 \%$ formic acid in $\mathrm{ACN} ; \mathrm{R}_{\mathrm{t}}=7.2 \mathrm{~min}$ ) were combined and lyophilized, providing the desired product (2) as a yellow solid (143 mg, 20\%). Data for 16: MS-HPLC (0 a 100\% B in $18 \mathrm{~min}$ ): $\mathrm{R}_{\mathrm{t}}=3.5 \mathrm{~min}$; MS (ESI, positive mode): $m / z 335.04[\mathrm{M}+\mathrm{H}]^{+}$(calcd mass for $\mathrm{C}_{13} \mathrm{H}_{19} \mathrm{~N}_{8} \mathrm{O}_{3}[\mathrm{M}+\mathrm{H}]^{+}:$335.1580). Data for 2 : $\operatorname{HPLC}(0$ a 50\% B in $30 \mathrm{~min}): \mathrm{t}_{\mathrm{R}}=14.6 \mathrm{~min} ;{ }^{1} \mathrm{H}$ NMR $(500 \mathrm{MHz}, D M S O) \delta(\mathrm{ppm}): 12.21$ $(1 \mathrm{H}, \mathrm{br} \mathrm{s}), 10.74(1 \mathrm{H}, \mathrm{br} \mathrm{s}), 9.10(1 \mathrm{H}, \mathrm{br} \mathrm{s}), 8.79(1 \mathrm{H}, \mathrm{s}), 7.06(4 \mathrm{H}, \mathrm{br} \mathrm{s}), 3.91(2 \mathrm{H}, \mathrm{t}, J=$ $7.0 \mathrm{~Hz}), 2.32(2 \mathrm{H}, \mathrm{t}, J=7.0 \mathrm{~Hz}), 1.88(2 \mathrm{H}, \mathrm{t}, J=7.0 \mathrm{~Hz}) ;{ }^{13} \mathrm{C} \mathrm{NMR}(100 \mathrm{MHz}, D M S O) \delta$ (ppm): 173.9, 167.7, 166.0, 163.9, 154.4, 149.6, 100.3, 49.0, 30.7, 24.4; HRMS (ESI, positive mode): $m / z 307.1261[\mathrm{M}+\mathrm{H}]^{+}$(calcd mass for $\mathrm{C}_{11} \mathrm{H}_{15} \mathrm{~N}_{8} \mathrm{O}_{3}[\mathrm{M}+\mathrm{H}]^{+}: 307.1267$ ). 


\section{Solid-phase synthesis of Janus-peptide derivatives (18 and 19).}

Fmoc-Asn(Trt)-Arg(Pbf)-Cys(Trt)-resin (17). The peptide was synthesized on a Rink amide $p$-MBHA resin $(\mathrm{f}=0.74 \mathrm{mmol} / \mathrm{g}, 100-200 \mathrm{mesh})$ using standard Fmoc/tBu chemistry with Fmoc-protected amino acids (4 mol equiv.), DIPC (4 mol equiv.) and HOAt (4 mol equiv.) for the coupling ( $2 \mathrm{~h}, \mathrm{DMF}$ ). The following side-chain protecting groups were used: Trt ( $N$-Trityl, asparagine; $S$-Trityl, cysteine), and $\operatorname{Pbf}\left(N^{G}-2,2,4,6,7-\right.$ pentamethyldihydrobenzofuran-5- sulfonyl, arginine).

\section{4-(4,7-Diamino-2-oxopyrimido[4,5-d]pyrimidin-1(2H)-yl)- $\mathrm{N}$-[Asn-Arg-Cys-}

$\mathbf{N H}_{2}$ ]butanamide (18). Peptide-bound resin 17 (60 mg, $0.044 \mathrm{mmol}, \mathrm{f} \sim 0.74 \mathrm{mmol} / \mathrm{g}$ ) was introduced into a polypropylene syringe fitted with a polyethylene disk, treated with $20 \%$ piperidine in DMF ( $2 \times 10 \mathrm{~min}$ ), washed successively (30 s washes) with DMF, DCM and $\mathrm{MeOH}$ and dried directly on a vacuum filtration system. Janus A monomer 1 (33 mg, 0.059 mmol) was activated with HATU (20.3 mg, $0.053 \mathrm{mmol})$ and DIPEA (19 $\mu \mathrm{L}, 0.111 \mathrm{mmol})$ in the minimum amount of anhydrous DMF for $2 \mathrm{~min}$, and the resulting yellow solution was added to the solid support, which was occasionally stirred with a Teflon rod for $4 \mathrm{~h}$ at RT. After vacuum filtration and washings ( $3 \times \mathrm{DMF}, 3 \times \mathrm{DCM}$ and $3 \times \mathrm{MeOH}$ ), side-chain deprotection and cleavage from the resin was performed simultaneously with TFA/TIS/ $\mathrm{H}_{2} \mathrm{O}$ 95:2.5:2.5 (1 mL) for $1 \mathrm{~h}$ at RT. Most of the TFA was removed by bubbling $\mathrm{N}_{2}$ into the solution, and the resulting residue was poured onto cold ether to precipitate the target compound. Analytical HPLC (linear gradient from 0 to $35 \%$ B in 30 min, A: $0.045 \%$ TFA in $\mathrm{H}_{2} \mathrm{O}$ and $\mathrm{B}: 0.036 \%$ TFA in $\left.\mathrm{ACN}\right)$, revealed the presence of a mail peak $\left(\mathrm{R}_{t}=13.1 \mathrm{~min}\right.$, 73\%) which was characterized as the desired compound 18. HRMS (ESI, positive mode): $m / z 637.2744[\mathrm{M}+\mathrm{H}]^{+}$(calcd mass for $\mathrm{C}_{23} \mathrm{H}_{37} \mathrm{~N}_{14} \mathrm{O}_{6} \mathrm{~S}[\mathrm{M}+\mathrm{H}]^{+}:$637.2736).

\section{4-(5-(4,6-Diamino-1,3,5-triazin-2-yl)cytosin-1(2H)-yl)- $N$-[Asn-Arg-Cys-}

$\mathbf{N H}_{2}$ ]butanamide (19). Peptide-bound resin 17 (34 mg, $0.025 \mathrm{mmol}, \mathrm{f} \sim 0.74 \mathrm{mmol} / \mathrm{g}$ ) was introduced into a polypropylene syringe fitted with a polyethylene disk, treated with $20 \%$ piperidine in DMF ( 2 x 10 min), washed successively (30 s washes) with DMF, DCM and $\mathrm{MeOH}$ and dried directly on a vacuum filtration system. Janus B monomer 2 (10 mg, 0.032 mmol) was activated with HATU (11.5 mg, $0.030 \mathrm{mmol})$ and DIPEA (11 $\mu \mathrm{L}, 0.629 \mathrm{mmol})$ in the minimum amount of anhydrous DMF for $2 \mathrm{~min}$, and the resulting yellow solution was added to the solid support, which was occasionally stirred with a Teflon rod for $4 \mathrm{~h}$ at RT. After vacuum filtration and washings ( $3 \times \mathrm{DMF}, 3 \times \mathrm{DCM}$ and $3 \times \mathrm{MeOH}$ ), side-chain deprotection and cleavage from the resin was performed with TFA/TIS/ $\mathrm{H}_{2} \mathrm{O}$ 95:2.5:2.5(1 
$\mathrm{mL}$ ) for $1 \mathrm{~h}$ at RT. Most of the TFA was removed by bubbling $\mathrm{N}_{2}$ into the solution, and the resulting residue was poured onto cold ether to precipitate the target compound. Analytical HPLC (linear gradient from 0 to $35 \% \mathrm{~B}$ in $30 \mathrm{~min}, \mathrm{~A}: 0.045 \%$ TFA in $\mathrm{H}_{2} \mathrm{O}$ and $\mathrm{B}$ : 0.036 $\%$ TFA in ACN), revealed the presence of a mail peak $\left(\mathrm{R}_{\mathrm{t}}=14.1 \mathrm{~min}, 54 \%\right)$ which was characterized as the desired compound 19. HRMS (ESI, positive mode): $m / z 679.2953$ $[\mathrm{M}+\mathrm{H}]^{+}$(calcd mass for $\mathrm{C}_{24} \mathrm{H}_{39} \mathrm{~N}_{16} \mathrm{O}_{6} \mathrm{~S}[\mathrm{M}+\mathrm{H}]^{+}$: 679.2954).

\section{Synthesis of Janus-Neamine ligands (20-23).}

General procedure. To a solution of 2,2'-dithiobis(5-nitropyridine) $(7.8 \mathrm{mg}, 25 \mu \mathrm{mol})$ in THF ( $2 \mathrm{~mL}$ ) was added under argon a solution of the neamine thiol derivative (Nea or Nea2, $2 \mu \mathrm{mol})^{11}$ in aqueous $0.1 \%$ TFA $(1 \mathrm{~mL})$, and the mixture was stirred at rt. After 15 h, THF was evaporated in vacuo and the remaining yellow solution was diluted with $\mathrm{H}_{2} \mathrm{O}$ $(2 \mathrm{~mL})$. The aqueous phase was washed with AcOEt to remove the excess of 2,2'dithiobis(5-nitropyridine) (typically $5 \times 2 \mathrm{~mL}$ or until no yellow colour was detected in the organic phase), lyophilized and dissolved again in aqueous $0.1 \%$ TFA (1 $\mathrm{mL})$ under argon. Then, a solution of 18 or $19(2 \mu \mathrm{mol})$ in $0.1 \% \mathrm{TFA} / \mathrm{H}_{2} \mathrm{O}(1 \mathrm{~mL})$ was added over the activated Janus-containing solution, and the mixture was stirred overnight under argon at rt. After purification by semipreparative reversed-phase HPLC (linear gradient from 0 to $35 \% \mathrm{~B}$ in $35 \mathrm{~min}$; $\mathrm{A}: 0.1 \%$ TFA in $\mathrm{H}_{2} \mathrm{O}$ and $\mathrm{B}: 0.036 \%$ TFA in ACN) and lyophilization, the TFA salt of the desired product was obtained as a white solid.

JanusA-Nea (20). Yield: $33 \%$. ${ }^{1} \mathrm{H}$ NMR (600 MHz, $\left.D_{2} O\right) \delta(p p m): 8.82\left(1 \mathrm{H}, \mathrm{H}_{\mathrm{Ar}}, \mathrm{s}\right), 5.45$ $\left(1 \mathrm{H}, \mathrm{H}_{1}, \mathrm{~m}\right), 4.63-4.61\left(2 \mathrm{H}, \mathrm{H}_{\alpha 1}, \mathrm{H}_{\alpha 3}, \mathrm{~m}\right), 4.35\left(1 \mathrm{H}, \mathrm{H}_{\alpha 2}, \mathrm{~m}\right), 4.17\left(2 \mathrm{H},-\mathrm{N}-\underline{\mathrm{CH}}_{2}-, \mathrm{m}\right), 3.99$ $\left(1 \mathrm{H}, \mathrm{H}_{5}, \mathrm{~m}\right), 3.91\left(1 \mathrm{H},-\mathrm{O}-\underline{\mathrm{CH}}_{2^{-}}, \mathrm{m}\right), 3.76\left(1 \mathrm{H},-\mathrm{O}-\underline{\mathrm{CH}}_{\underline{2}^{-}}, \mathrm{m}\right), 3.65\left(1 \mathrm{H}, \mathrm{H}_{6}, \mathrm{~m}\right), 3.49(2 \mathrm{H}$, $\left.\mathrm{H}_{4}, \mathrm{H}_{5}, \mathrm{~m}\right), 3.40$ (3H, $\left.\mathrm{H}_{2}, \mathrm{H}_{3}, \mathrm{H}_{4}, \mathrm{~m}\right), 3.19$ (5H, $\left.\mathrm{H}_{6}, \mathrm{H}_{\delta 2}, \mathrm{H}_{\beta 3}, \mathrm{~m}\right), 2.94\left(1 \mathrm{H}, \mathrm{H}_{\beta 3}, \mathrm{~m}\right), 2.83$ $\left(1 \mathrm{H}, \mathrm{H}_{\beta 1}, \mathrm{~m}\right), 2.78\left(1 \mathrm{H}, \mathrm{H}_{\beta 1}, \mathrm{~m}\right), 2.67\left(2 \mathrm{H},-\mathrm{S}-\underline{\mathrm{CH}}_{2}{ }^{-}, \mathrm{m}\right), 2.40\left(2 \mathrm{H},-\underline{\mathrm{CH}}_{2}-\mathrm{CO}-, \mathrm{m}\right), 2.16$ $\left(2 \mathrm{H}, \mathrm{H}_{1}, \mathrm{H}_{3}, \mathrm{~m}\right), 1.99\left(2 \mathrm{H},-\mathrm{N}-\mathrm{CH}_{2}-\underline{\mathrm{CH}}_{2} \underline{2}^{-}, \mathrm{m}\right), 1.92\left(1 \mathrm{H}, \mathrm{H}_{\beta 2}, \mathrm{~m}\right), 1.81\left(1 \mathrm{H}, \mathrm{H}_{\beta 2}, \mathrm{~m}\right), 1.61$ (7H, $\left.\mathrm{H}_{2, \mathrm{eq}}, \mathrm{H}_{2},-\mathrm{O}-\mathrm{CH}_{2}-\underline{\mathrm{CH}}_{2}^{-}, \mathrm{S}-\mathrm{CH}_{2}-\underline{\mathrm{CH}}_{2}^{-}, \mathrm{m}\right), 1.33\left(5 \mathrm{H}, \mathrm{H}_{2, \mathrm{ax}},-\mathrm{O}-\mathrm{CH}_{2}-\mathrm{CH}_{2}-\underline{\mathrm{CH}}_{2}-\mathrm{CH}_{2} \underline{2}^{-}\right.$, m); HRMS (ESI, positive mode): $m / z 1073.5088[\mathrm{M}+\mathrm{H}]^{+}$(calcd mass for $\mathrm{C}_{41} \mathrm{H}_{73} \mathrm{~N}_{18} \mathrm{O}_{12} \mathrm{~S}_{2}$ $[\mathrm{M}+\mathrm{H}]^{+}:$1073.5097); analytical reversed-phase HPLC (0 a 35\% B in $\left.35 \mathrm{~min}\right): \mathrm{R}_{\mathrm{t}}=17.8$ $\min$.

JanusA-Nea2 (21). Yield: $21 \%$. ${ }^{1} \mathrm{H}$ NMR $\left(600 \mathrm{MHz}, D_{2} O\right) \delta(\mathrm{ppm}): 8.77\left(1 \mathrm{H}, \mathrm{H}_{\mathrm{Ar}}, \mathrm{s}\right)$, $5.81\left(1 \mathrm{H}, \mathrm{H}_{1}, \mathrm{~d}, J=3.8 \mathrm{~Hz}\right), 4.61\left(1 \mathrm{H}, \mathrm{H}_{\alpha 3}, \mathrm{~m}\right), 4.56\left(1 \mathrm{H}, \mathrm{H}_{\alpha 1}, \mathrm{t}, J=7.0 \mathrm{~Hz}\right), 4.29(1 \mathrm{H}$, 
$\left.\mathrm{H}_{\alpha 2}, \mathrm{~m}\right), 4.18\left(1 \mathrm{H},-\mathrm{O}-\underline{\mathrm{CH}}_{2}-, \mathrm{m}\right), 4.07\left(2 \mathrm{H},-\mathrm{N}-\underline{\mathrm{CH}}_{\underline{2}^{-}}, \mathrm{m}\right), 3.92\left(2 \mathrm{H}, \mathrm{H}_{5},-\mathrm{O}-\underline{\mathrm{CH}}_{2^{-}}, \mathrm{m}\right), 3.68$ $\left(1 \mathrm{H}, \mathrm{H}_{6}, \mathrm{~m}\right), 3.49$ (2H, $\left.\mathrm{H}_{6}, \mathrm{~m}\right), 3.41\left(3 \mathrm{H}, \mathrm{H}_{4}, \mathrm{H}_{4}, \mathrm{H}_{3}, \mathrm{~m}\right), 3.29\left(2 \mathrm{H}, \mathrm{H}_{2}, \mathrm{H}_{5}, \mathrm{~m}\right), 3.17(1 \mathrm{H}$, $\left.\mathrm{H}_{\beta 3}, \mathrm{~m}\right), 3.06\left(2 \mathrm{H}, \mathrm{H}_{\delta 2}, \mathrm{~m}\right), 2.91\left(3 \mathrm{H},-\mathrm{S}-\underline{\mathrm{CH}}_{2}-\mathrm{H}_{\beta 3}, \mathrm{~m}\right), 2.77\left(1 \mathrm{H}, \mathrm{H}_{\beta 1}, \mathrm{~m}\right), 2.67\left(1 \mathrm{H}, \mathrm{H}_{\beta 1}\right.$, m), $2.38\left(2 \mathrm{H}, \mathrm{H}_{1}, \mathrm{H}_{3}, \mathrm{~m}\right), 2.33\left(2 \mathrm{H},-\underline{\mathrm{CH}}_{2}-\mathrm{CO}-, \mathrm{m}\right), 1.91\left(2 \mathrm{H},-\mathrm{N}-\mathrm{CH}_{2}-\underline{\mathrm{CH}}_{2}-, m\right), 1.88(1 \mathrm{H}$, $\left.\mathrm{H}_{\beta 2}, \mathrm{~m}\right), 1.73\left(2 \mathrm{H}, \mathrm{H}_{\beta 2}, \mathrm{H}_{2, \mathrm{eq}}, \mathrm{m}\right), 1.55\left(3 \mathrm{H}, \mathrm{H}_{\gamma 2}, \mathrm{H}_{2, \mathrm{ax}}, \mathrm{m}\right)$; HRMS (ESI, positive mode): $m / z$ 1017.4431 $[\mathrm{M}+\mathrm{H}]^{+}$(calcd mass for $\mathrm{C}_{37} \mathrm{H}_{65} \mathrm{~N}_{18} \mathrm{O}_{12} \mathrm{~S}_{2}[\mathrm{M}+\mathrm{H}]^{+}:$1017.4471); analytical reversed-phase HPLC ( 0 a $35 \% \mathrm{~B}$ in $30 \mathrm{~min}$ ): $\mathrm{R}_{\mathrm{t}}=13.3 \mathrm{~min}$.

JanusB-Nea (22). Yield: $21 \%$. ${ }^{1} \mathrm{H}$ NMR (600 MHz, $\left.D_{2} O\right) \delta(p p m): 8.72\left(1 \mathrm{H}, \mathrm{H}_{\mathrm{Ar}}, \mathrm{s}\right), 5.67$ $\left(1 \mathrm{H}, \mathrm{H}_{1}, \mathrm{~m}\right), 4.61\left(1 \mathrm{H}, \mathrm{H}_{\alpha 3}, \mathrm{~m}\right), 4.58\left(1 \mathrm{H}, \mathrm{H}_{\alpha 1}, \mathrm{t}, J=6.9 \mathrm{~Hz}\right), 4.34\left(1 \mathrm{H}, \mathrm{H}_{\alpha 2}, \mathrm{~m}\right), 3.96(1 \mathrm{H}$, $\left.-\mathrm{O}-\underline{\mathrm{CH}}_{2}-1, \mathrm{~m}\right), 3.88\left(3 \mathrm{H},-\mathrm{N}-\underline{\mathrm{CH}}_{2}^{-}, \mathrm{H}_{5}, \mathrm{~m}\right), 3.75\left(1 \mathrm{H},-\mathrm{O}-\underline{\mathrm{CH}}_{2}-, \mathrm{m}\right), 3.63\left(2 \mathrm{H}, \mathrm{H}_{4}, \mathrm{H}_{6}, \mathrm{~m}\right)$, $3.60\left(1 \mathrm{H}, \mathrm{H}_{3}, \mathrm{~m}\right), 3.45\left(3 \mathrm{H}, \mathrm{H}_{2}, \mathrm{H}_{4}, \mathrm{H}_{5}, \mathrm{~m}\right), 3.25\left(2 \mathrm{H}, \mathrm{H}_{6}, \mathrm{~m}\right), 3.19\left(3 \mathrm{H}, \mathrm{H}_{\delta 2}, \mathrm{H}_{\beta 3}, \mathrm{~m}\right), 2.94$ $\left(1 \mathrm{H}, \mathrm{H}_{\beta 3}, \mathrm{~m}\right), 2.80\left(1 \mathrm{H}, \mathrm{H}_{\beta 1}, \mathrm{~m}\right), 2.76\left(1 \mathrm{H}, \mathrm{H}_{\beta 1}, \mathrm{~m}\right), 2.67$ (2H, -S- $\left.\underline{\mathrm{CH}}_{2}-, \mathrm{m}\right), 2.40$ (2H, $\left.\underline{\mathrm{CH}}_{2}-\mathrm{CO}-, \mathrm{t}, J=7.4 \mathrm{~Hz}\right), 2.27\left(2 \mathrm{H}, \mathrm{H}_{1}, \mathrm{H}_{3}, \mathrm{~m}\right), 2.06\left(2 \mathrm{H},-\mathrm{N}^{-\mathrm{CH}_{2}-\underline{\mathrm{CH}}_{2}-}, \mathrm{m}\right), 1.89\left(1 \mathrm{H}, \mathrm{H}_{\beta 2}\right.$, m), $1.80\left(1 \mathrm{H}, \mathrm{H}_{\beta 2}, \mathrm{~m}\right), 1.60\left(7 \mathrm{H},-\mathrm{S}-\mathrm{CH}_{2}-\underline{\mathrm{CH}}_{2}-, \mathrm{O}_{-} \mathrm{CH}_{2}-\underline{\mathrm{CH}}_{2}-, \mathrm{H}_{2, \mathrm{eq}}, \mathrm{H}_{\gamma}, \mathrm{m}\right), 1.32\left(5 \mathrm{H}, \mathrm{H}_{2, \mathrm{ax}}\right.$, -O- $\mathrm{CH}_{2}-\mathrm{CH}_{2}-\underline{\mathrm{CH}}_{2}-\underline{\mathrm{CH}}_{2}-$, m); HRMS (ESI, positive mode): $\mathrm{m} / z 1115.5302[\mathrm{M}+\mathrm{H}]^{+}$(calcd mass for $\mathrm{C}_{42} \mathrm{H}_{75} \mathrm{~N}_{20} \mathrm{O}_{12} \mathrm{~S}_{2}[\mathrm{M}+\mathrm{H}]^{+}:$1115.5315); analytical reversed-phase HPLC (0 a 35\% $\mathrm{B}$ in $35 \mathrm{~min})$ : $\mathrm{R}_{\mathrm{t}}=18.5 \mathrm{~min}$.

JanusB-Nea2 (23). Yield: $53 \%{ }^{1} \mathrm{H}$ NMR (600 MHz, $\left.D_{2} O\right) \delta(\mathrm{ppm}): 8.70\left(1 \mathrm{H}, \mathrm{H}_{\mathrm{Ar}}, \mathrm{s}\right)$, $5.70\left(1 \mathrm{H}, \mathrm{H}_{1}, \mathrm{~m}\right), 4.66\left(1 \mathrm{H}, \mathrm{H}_{\alpha 3}, \mathrm{~m}\right), 4.60\left(1 \mathrm{H}, \mathrm{H}_{\alpha 1}, \mathrm{t}, J=6.9 \mathrm{~Hz}\right), 4.34\left(1 \mathrm{H}, \mathrm{H}_{\alpha 2}, \mathrm{~m}\right), 4.18$ $\left(1 \mathrm{H},-\mathrm{O}-\underline{\mathrm{CH}}_{2^{-}}, \mathrm{m}\right), 3.99\left(2 \mathrm{H}, \mathrm{H}_{5},-\mathrm{O}-\underline{\mathrm{CH}}_{2} \underline{2}^{-}, \mathrm{m}\right), 3.94\left(2 \mathrm{H},-\mathrm{N}-\underline{\mathrm{CH}}_{2} \underline{2}^{-}, \mathrm{m}\right), 3.65\left(2 \mathrm{H}, \mathrm{H}_{4}, \mathrm{H}_{6}\right.$, m), $3.46\left(3 \mathrm{H}, \mathrm{H}_{5}, \mathrm{H}_{3}, \mathrm{H}_{4}, \mathrm{~m}\right), 3.25\left(4 \mathrm{H}, \mathrm{H}_{2}, \mathrm{H}_{6}, \mathrm{H}_{\beta 3}, \mathrm{~m}\right), 3.17\left(2 \mathrm{H}, \mathrm{H}_{\delta 2}, \mathrm{t}, J=7.3 \mathrm{~Hz}\right), 2.99$ (3H, -S- $\left.\underline{\mathrm{CH}}_{\underline{2}^{-}}, \mathrm{H}_{\beta 3}, \mathrm{~m}\right), 2.81\left(1 \mathrm{H}, \mathrm{H}_{\beta 1}, \mathrm{~m}\right), 2.73\left(1 \mathrm{H}, \mathrm{H}_{\beta 1}, \mathrm{~m}\right), 2.41\left(2 \mathrm{H},-\underline{\mathrm{CH}}_{2}-\mathrm{CO}-, \mathrm{t}, J=7.2\right.$ $\mathrm{Hz}), 2.25\left(2 \mathrm{H}, \mathrm{H}_{1}, \mathrm{H}_{3}, \mathrm{~m}\right), 2.07\left(2 \mathrm{H},-\mathrm{N}-\mathrm{CH}_{2}-\underline{\mathrm{CH}}_{2}{ }^{-}, \mathrm{m}\right), 1.91\left(1 \mathrm{H}, \mathrm{H}_{\beta 2}, \mathrm{~m}\right), 1.79\left(2 \mathrm{H}, \mathrm{H}_{2, \mathrm{eq}}\right.$, $\left.\mathrm{H}_{\beta 2}, \mathrm{~m}\right), 1.60\left(3 \mathrm{H}, \mathrm{H}_{2, \mathrm{ax}}, \mathrm{H}_{\gamma_{2}}, \mathrm{~m}\right)$; HRMS (ESI, positive mode): $m / z 1059.4675[\mathrm{M}+\mathrm{H}]^{+}$ (calcd mass for $\mathrm{C}_{38} \mathrm{H}_{67} \mathrm{~N}_{20} \mathrm{O}_{12} \mathrm{~S}_{2}[\mathrm{M}+\mathrm{H}]^{+}$: 1059.4689); analytical reversed-phase HPLC (0 a $35 \% \mathrm{~B}$ in $30 \mathrm{~min}$ ): $\mathrm{R}_{\mathrm{t}}=14.8 \mathrm{~min}$.

\section{Synthesis of Janus-Guanidinoneamine ligands (24-27).}

General procedure. Janus-Neamine ligand (20-23, $300 \mathrm{nmol})$ and 1,3-di-Boc-2trifluoromethylsulfonyl)guanidine $(4.7 \mathrm{mg}, 12 \mu \mathrm{mol})$ were dissolved in a 5:3 (v/v) mixture of $\mathrm{MeOH} / \mathrm{CHCl}_{3}(0.5 \mathrm{~mL})$ under argon atmosphere. Then, triethylamine $(10 \mu \mathrm{L}, 72 \mu \mathrm{mol})$ was added and the reaction mixture was stirred for 4 days at rt under Ar. After evaporation 
in vacuo, the crude was diluted with DCM $(5 \mathrm{~mL})$ and washed with a $10 \%$ aqueous solution of citric acid $(3 \times 1 \mathrm{~mL})$ and with brine $(3 \times 1 \mathrm{~mL})$. The organic phase was taken up and dried over anhydrous $\mathrm{MgSO}_{4}$, filtered and concentrated in vacuo to dryness. The crude was dissolved in a 1:1 (v/v) mixture of TFA/DCM $(0.5 \mathrm{~mL})$ and TIS $(12.5 \mu \mathrm{L}, 61 \mu \mathrm{mol})$ was added. After stirring at $\mathrm{rt}$ for $2 \mathrm{~h}$ under Ar, the mixture was diluted with toluene $(2 \mathrm{~mL})$ and evaporated in vacuo. After several co-evaporations from toluene, the residue was dissolved in Milli-Q $\mathrm{H}_{2} \mathrm{O}(5 \mathrm{~mL})$ and lyophilized to provide a white solid. Purification was carried out by analytical reversed-phase HPLC (linear gradient from 0 to $25 \%$ B in $35 \mathrm{~min}$; A: $0.045 \%$ TFA in $\mathrm{H}_{2} \mathrm{O}$ and $\mathrm{B}: 0.036 \%$ TFA in ACN), and the TFA salt of the desired product was obtained after lyophilization.

JanusA-NeaG4 (24). Yield: $24 \%$. ${ }^{1} \mathrm{H}$ NMR $\left(600 \mathrm{MHz}, D_{2} O\right) \delta(\mathrm{ppm}): 8.81\left(1 \mathrm{H}, \mathrm{H}_{\mathrm{Ar}}, \mathrm{s}\right)$, $5.59\left(1 \mathrm{H}, \mathrm{H}_{1}, \mathrm{~d}, J=4.0 \mathrm{~Hz}\right), 4.61\left(2 \mathrm{H}, \mathrm{H}_{\alpha 1}, \mathrm{H}_{\alpha 3}, \mathrm{~m}\right), 4.35\left(1 \mathrm{H}, \mathrm{H}_{\alpha 2}, \mathrm{~m}\right), 4.13\left(2 \mathrm{H},-\mathrm{N}^{-\mathrm{CH}_{2}} \underline{-}^{-}\right.$ , m), 3.98 (1H, -O- $\left.\underline{\mathrm{CH}}_{2}^{-}, \mathrm{m}\right), 3.72-3.45\left(10 \mathrm{H},-\mathrm{O}-\underline{\mathrm{CH}}_{2}^{-}, \mathrm{H}_{2}, \mathrm{H}_{3}, \mathrm{H}_{4}, \mathrm{H}_{5}, \mathrm{H}_{6}, \mathrm{H}_{4}, \mathrm{H}_{5}, \mathrm{H}_{6}\right.$, m), $3.20\left(1 \mathrm{H}, \mathrm{H}_{\beta 3}, \mathrm{~m}\right), 3.16\left(2 \mathrm{H}, \mathrm{H}_{\delta 2}, \mathrm{~m}\right), 2.92\left(1 \mathrm{H}, \mathrm{H}_{\beta 3}, \mathrm{~m}\right), 2.81\left(1 \mathrm{H}, \mathrm{H}_{\beta 1}, \mathrm{~m}\right), 2.76(1 \mathrm{H}$, $\left.\mathrm{H}_{\beta 1}, \mathrm{~m}\right), 2.66\left(2 \mathrm{H},-\mathrm{S}-\underline{\mathrm{CH}}_{2}-, \mathrm{m}\right), 2.41\left(2 \mathrm{H},-\underline{\mathrm{CH}}_{2}-\mathrm{CO}-, \mathrm{m}\right), 2.25\left(2 \mathrm{H}, \mathrm{H}_{1}, \mathrm{H}_{3}, \mathrm{~m}\right), 1.98(2 \mathrm{H},-$ $\left.\mathrm{N}-\mathrm{CH}_{2}-\underline{\mathrm{CH}}_{2}{ }^{-}, \mathrm{m}\right), 1.90\left(1 \mathrm{H}, \mathrm{H}_{\beta 2}, \mathrm{~m}\right), 1.81\left(1 \mathrm{H}, \mathrm{H}_{\beta 2}, \mathrm{~m}\right), 1.59\left(5 \mathrm{H}, \mathrm{H}_{2, \mathrm{eq}}, \mathrm{H}_{\gamma 2},-\mathrm{S}^{-} \mathrm{CH}_{2}-\underline{\mathrm{CH}}_{2}{ }^{-}\right.$,

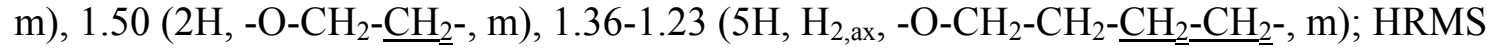
(ESI, positive mode): $m / z 621.3023[\mathrm{M}+2 \mathrm{H}]^{2+}$ (calcd mass for $\mathrm{C}_{45} \mathrm{H}_{82} \mathrm{~N}_{26} \mathrm{O}_{12} \mathrm{~S}_{2}[\mathrm{M}+2 \mathrm{H}]^{2+}$ : 621.3024), $m / z 414.5366[\mathrm{M}+3 \mathrm{H}]^{3+}$ (calcd mass for $\mathrm{C}_{45} \mathrm{H}_{83} \mathrm{~N}_{26} \mathrm{O}_{12} \mathrm{~S}_{2}[\mathrm{M}+3 \mathrm{H}]^{3+}$ : 414.5375), $m / z 311.1542[\mathrm{M}+4 \mathrm{H}]^{4+}$ (calcd mass for $\mathrm{C}_{45} \mathrm{H}_{84} \mathrm{~N}_{26} \mathrm{O}_{12} \mathrm{~S}_{2}[\mathrm{M}+\mathrm{H}]^{+}: 311.1551$ ); analytical reversed-phase HPLC ( 0 a 25\% B in $35 \mathrm{~min}$ ): $\mathrm{R}_{\mathrm{t}}=23.4 \mathrm{~min}$.

JanusA-Nea2G4 (25). Yield: $24 \%$. ${ }^{1} \mathrm{H}$ NMR (600 MHz, $\left.D_{2} O\right) \delta(\mathrm{ppm}): 8.81\left(1 \mathrm{H}, \mathrm{H}_{\mathrm{Ar}}, \mathrm{s}\right)$, $5.66\left(1 \mathrm{H}, \mathrm{H}_{1}, \mathrm{~d}, J=4.0 \mathrm{~Hz}\right), 4.65\left(1 \mathrm{H}, \mathrm{H}_{\alpha 3}, \mathrm{~m}\right), 4.62\left(1 \mathrm{H}, \mathrm{H}_{\alpha 1}, \mathrm{t}, J=7.0 \mathrm{~Hz}\right), 4.35(1 \mathrm{H}$, $\left.\mathrm{H}_{\alpha 2}, \mathrm{~m}\right), 4.21\left(1 \mathrm{H},-\mathrm{O}-\underline{\mathrm{CH}}_{2^{-}}, \mathrm{m}\right), 4.12\left(2 \mathrm{H},-\mathrm{N}-\underline{\mathrm{CH}}_{2^{-}}, \mathrm{m}\right), 3.81\left(1 \mathrm{H},-\mathrm{O}-\underline{\mathrm{CH}}_{2^{-}}, \mathrm{m}\right), 3.73(2 \mathrm{H}$, $\left.\mathrm{H}_{5}, \mathrm{H}_{6}, \mathrm{~m}\right), 3.63\left(1 \mathrm{H}, \mathrm{H}_{2}, \mathrm{~m}\right), 3.56\left(4 \mathrm{H}, \mathrm{H}_{3}, \mathrm{H}_{4}, \mathrm{H}_{4}, \mathrm{H}_{5}, \mathrm{~m}\right), 3.47\left(2 \mathrm{H}, \mathrm{H}_{6}, \mathrm{~m}\right), 3.23(1 \mathrm{H}$, $\left.\mathrm{H}_{\beta 3}, \mathrm{~m}\right), 3.14\left(2 \mathrm{H}, \mathrm{H}_{\delta 2}, \mathrm{~m}\right), 2.92\left(3 \mathrm{H},-\mathrm{S}-\underline{\mathrm{CH}}_{2}-\mathrm{H}_{\beta 3}, \mathrm{~m}\right), 2.81\left(1 \mathrm{H}, \mathrm{H}_{\beta 1}, \mathrm{~m}\right), 2.75\left(1 \mathrm{H}, \mathrm{H}_{\beta 1}\right.$, m), $2.40\left(2 \mathrm{H},-\underline{\mathrm{CH}_{2}}-\mathrm{CO}-, \mathrm{m}\right), 2.23\left(2 \mathrm{H}, \mathrm{H}_{1}, \mathrm{H}_{3}, \mathrm{~m}\right), 1.98\left(2 \mathrm{H},-\mathrm{N}-\mathrm{CH}_{2}-\underline{\mathrm{CH}}_{\underline{2}^{-}}, \mathrm{m}\right), 1.90(1 \mathrm{H}$, $\left.\mathrm{H}_{\beta 2}, \mathrm{~m}\right), 1.79$ (2H, $\left.\mathrm{H}_{\beta 2}, \mathrm{H}_{2, \mathrm{eq}}, \mathrm{m}\right), 1.62\left(3 \mathrm{H}, \mathrm{H}_{\gamma 2}, \mathrm{H}_{2, \mathrm{ax}}, \mathrm{m}\right)$ ) HRMS (ESI, positive mode): $m / z 593.2696[\mathrm{M}+2 \mathrm{H}]^{2+}$ (calcd mass for $\mathrm{C}_{41} \mathrm{H}_{74} \mathrm{~N}_{26} \mathrm{O}_{12} \mathrm{~S}_{2}[\mathrm{M}+2 \mathrm{H}]^{2+}: 593.2711$ ), $m / z$ $395.8489[\mathrm{M}+3 \mathrm{H}]^{3+}$ (calcd mass for $\left.\mathrm{C}_{41} \mathrm{H}_{75} \mathrm{~N}_{26} \mathrm{O}_{12} \mathrm{~S}_{2}[\mathrm{M}+3 \mathrm{H}]^{3+}: 395.8500\right), m / z 297.1388$ $[\mathrm{M}+4 \mathrm{H}]^{4+}$ (calcd mass for $\mathrm{C}_{41} \mathrm{H}_{76} \mathrm{~N}_{26} \mathrm{O}_{12} \mathrm{~S}_{2}[\mathrm{M}+\mathrm{H}]^{+}:$297.1394); analytical reversed-phase $\operatorname{HPLC}\left(0\right.$ a $25 \%$ B in $35 \mathrm{~min}$ ): $\mathrm{R}_{\mathrm{t}}=17.8 \mathrm{~min}$. 
JanusB-NeaG4 (26). Yield: $25 \%$. ${ }^{1} \mathrm{H}$ NMR (600 MHz, $\left.D_{2} O\right) \delta(\mathrm{ppm}): 8.73\left(1 \mathrm{H}, \mathrm{H}_{\mathrm{Ar}}, \mathrm{s}\right)$, $5.59\left(1 \mathrm{H}, \mathrm{H}_{1}\right.$, d,$\left.J=4.0 \mathrm{~Hz}\right), 4.61\left(1 \mathrm{H}, \mathrm{H}_{\alpha 3}, \mathrm{~m}\right), 4.58\left(1 \mathrm{H}, \mathrm{H}_{\alpha 1}, \mathrm{t}, J=6.9 \mathrm{~Hz}\right), 4.34\left(1 \mathrm{H}, \mathrm{H}_{\alpha 2}\right.$, m), $3.98\left(1 \mathrm{H},-\mathrm{O}-\underline{\mathrm{CH}}_{2^{-}}, \mathrm{m}\right), 3.91\left(2 \mathrm{H},-\mathrm{N}-\underline{\mathrm{CH}}_{2}^{-}, \mathrm{m}\right), 3.70-3.45\left(10 \mathrm{H},-\mathrm{O}-\underline{\mathrm{CH}}_{2} \underline{2}^{-}, \mathrm{H}_{2}, \mathrm{H}_{3}, \mathrm{H}_{4}\right.$, $\left.\mathrm{H}_{5}, \mathrm{H}_{6}, \mathrm{H}_{4}, \mathrm{H}_{5}, \mathrm{H}_{6}, \mathrm{~m}\right), 3.18\left(3 \mathrm{H}, \mathrm{H}_{\delta 2}, \mathrm{H}_{\beta 3}, \mathrm{~m}\right), 2.94\left(1 \mathrm{H}, \mathrm{H}_{\beta 3}, \mathrm{~m}\right), 2.80\left(1 \mathrm{H}, \mathrm{H}_{\beta 1}, \mathrm{~m}\right)$, $2.74\left(1 \mathrm{H}, \mathrm{H}_{\beta 1}, \mathrm{~m}\right), 2.66\left(2 \mathrm{H},-\mathrm{S}-\underline{\mathrm{CH}}_{2}-, \mathrm{m}\right), 2.42\left(2 \mathrm{H},-\underline{\mathrm{CH}}_{2}-\mathrm{CO}-, \mathrm{t}, J=7.3 \mathrm{~Hz}\right), 2.25(2 \mathrm{H}$, $\left.\mathrm{H}_{1}, \mathrm{H}_{3}, \mathrm{~m}\right), 2.07\left(2 \mathrm{H},-\mathrm{N}-\mathrm{CH}_{2}-\underline{\mathrm{CH}}_{2}^{-}, \mathrm{m}\right), 1.90\left(1 \mathrm{H}, \mathrm{H}_{\beta 2}, \mathrm{~m}\right), 1.82\left(1 \mathrm{H}, \mathrm{H}_{\beta 2}, \mathrm{~m}\right), 1.59$ (5H, S$\left.\mathrm{CH}_{2}-\underline{\mathrm{CH}}_{2}-, \mathrm{H}_{2, \mathrm{eq}}, \mathrm{H}_{2}, \mathrm{~m}\right), 1.49\left(2 \mathrm{H},-\mathrm{O}-\mathrm{CH}_{2}-\underline{\mathrm{CH}}_{2}-, \mathrm{m}\right), 1.32-1.25\left(5 \mathrm{H}, \mathrm{H}_{2, \mathrm{ax}},-\mathrm{O}-\mathrm{CH}_{2}-\mathrm{CH}_{2}-\right.$ $\underline{\mathrm{CH}}_{2}-\underline{C H}_{2}-, m$ ); HRMS (ESI, positive mode): $m / z 642.3114[\mathrm{M}+2 \mathrm{H}]^{2+}($ calcd mass for $\mathrm{C}_{46} \mathrm{H}_{84} \mathrm{~N}_{28} \mathrm{O}_{12} \mathrm{~S}_{2}[\mathrm{M}+2 \mathrm{H}]^{2+}: 642.3132$ ), $m / z 428.5420[\mathrm{M}+3 \mathrm{H}]^{3+}$ (calcd mass for $\mathrm{C}_{46} \mathrm{H}_{85} \mathrm{~N}_{28} \mathrm{O}_{12} \mathrm{~S}_{2}[\mathrm{M}+3 \mathrm{H}]^{3+}$ : 428.5448), $m / z 321.6584[\mathrm{M}+4 \mathrm{H}]^{4+}$ (calcd mass for $\left.\mathrm{C}_{46} \mathrm{H}_{86} \mathrm{~N}_{28} \mathrm{O}_{12} \mathrm{~S}_{2}[\mathrm{M}+4 \mathrm{H}]^{4+}: 321.6605\right)$; analytical reversed-phase HPLC (0 a 25\% B in 35 $\min ): \mathrm{R}_{\mathrm{t}}=24.1 \mathrm{~min}$.

JanusB-NeaG4 (27). Yield: $23 \%$. ${ }^{1} \mathrm{H}$ NMR $\left(600 \mathrm{MHz}, D_{2} O\right) \delta(\mathrm{ppm}): 8.71\left(1 \mathrm{H}, \mathrm{H}_{\mathrm{Ar}}, \mathrm{s}\right)$, $5.65\left(1 \mathrm{H}, \mathrm{H}_{1}, \mathrm{~d}, J=4.0 \mathrm{~Hz}\right), 4.65\left(1 \mathrm{H}, \mathrm{H}_{\alpha 3}, \mathrm{~m}\right), 4.60\left(1 \mathrm{H}, \mathrm{H}_{\alpha 1}, \mathrm{t}, J=7.0 \mathrm{~Hz}\right), 4.34(1 \mathrm{H}$, $\left.\mathrm{H}_{\alpha 2}, \mathrm{~m}\right), 4.21\left(1 \mathrm{H},-\mathrm{O}-\underline{\mathrm{CH}}_{2}^{-}, \mathrm{m}\right), 3.93\left(2 \mathrm{H},-\mathrm{N}-\underline{\mathrm{CH}}_{2}^{-}, \mathrm{m}\right), 3.82\left(1 \mathrm{H},-\mathrm{O}-\underline{\mathrm{CH}}_{2}^{-}, \mathrm{m}\right), 3.71(3 \mathrm{H}$, $\left.\mathrm{H}_{2}, \mathrm{H}_{5}, \mathrm{H}_{6}, \mathrm{~m}\right), 3.55\left(4 \mathrm{H}, \mathrm{H}_{4}, \mathrm{H}_{5}, \mathrm{H}_{3}, \mathrm{H}_{4}, \mathrm{~m}\right), 3.48\left(2 \mathrm{H}, \mathrm{H}_{6}, \mathrm{~m}\right), 3.25\left(1 \mathrm{H}, \mathrm{H}_{\beta 3}, \mathrm{~m}\right), 3.17$ $\left(2 \mathrm{H}, \mathrm{H}_{\delta 2}, \mathrm{~m}\right), 2.96\left(3 \mathrm{H},-\mathrm{S}-\underline{\mathrm{CH}}_{2}-\mathrm{H}_{\beta 3}, \mathrm{~m}\right), 2.81\left(1 \mathrm{H}, \mathrm{H}_{\beta 1}, \mathrm{~m}\right), 2.72\left(1 \mathrm{H}, \mathrm{H}_{\beta 1}, \mathrm{~m}\right), 2.41(2 \mathrm{H}$, $\left.-\underline{\mathrm{CH}}_{2}-\mathrm{CO}, \mathrm{t}, J=7.2 \mathrm{~Hz}\right), 2.24\left(2 \mathrm{H}, \mathrm{H}_{1}, \mathrm{H}_{3}, \mathrm{~m}\right), 2.07\left(2 \mathrm{H},-\mathrm{N}-\mathrm{CH}_{2}-\underline{\mathrm{CH}}_{2}-, \mathrm{m}\right), 1.90\left(1 \mathrm{H}, \mathrm{H}_{\beta 2}\right.$, m), $1.79\left(2 \mathrm{H}, \mathrm{H}_{2, \text { eq }}, \mathrm{H}_{\beta 2}, \mathrm{~m}\right), 1.62\left(3 \mathrm{H}, \mathrm{H}_{2, \mathrm{ax}}, \mathrm{H}_{\gamma 2}, \mathrm{~m}\right) ; \mathrm{HRMS}$ (ESI, positive mode): $m / z$ $614.2806[\mathrm{M}+2 \mathrm{H}]^{2+}$ (calcd mass for $\mathrm{C}_{42} \mathrm{H}_{76} \mathrm{~N}_{28} \mathrm{O}_{12} \mathrm{~S}_{2}[\mathrm{M}+2 \mathrm{H}]^{2+}$ : 614.2819), $m / z 409.8561$ $[\mathrm{M}+3 \mathrm{H}]^{3+}$ (calcd mass for $\mathrm{C}_{42} \mathrm{H}_{77} \mathrm{~N}_{28} \mathrm{O}_{12} \mathrm{~S}_{2}[\mathrm{M}+3 \mathrm{H}]^{3+}$ : 409.8572), $m / z 307.6442[\mathrm{M}+4 \mathrm{H}]^{4+}$ (calcd mass for $\mathrm{C}_{42} \mathrm{H}_{78} \mathrm{~N}_{28} \mathrm{O}_{12} \mathrm{~S}_{2}[\mathrm{M}+\mathrm{H}]^{+}$: 307.6449); analytical reversed-phase HPLC (0 a $25 \% \mathrm{~B}$ in $35 \mathrm{~min}$ ): $\mathrm{R}_{\mathrm{t}}=19.2 \mathrm{~min}$.

\section{Evaluation of the interaction between Tau RNA and Janus-containing ligands.}

Oligoribonucleotides were synthesized using 2'-O-tert-butyldimethylsilyl (TBDMS) protection and following standard procedures (phosphite triester approach). RNA, fluorescein and 2-AP phosphoramidites, solid-supports, reagents and solvents for oligoribonucleotide synthesis were purchased from Glen Research or Link Technologies. The syntheses (1- $\mu$ mol scale) were performed on an ABI 3400 DNA automatic synthesizer according to the manufacturer's synthesis procedure, with some modifications. ${ }^{11 a}$ Cleavage 
and deprotection from the solid support were carried out following a stepwise protocol. ${ }^{11 \mathrm{a}, 28}$ RNase-free reagents, solutions and materials were used when manipulating deprotected oligoribonucleotides. RNase-free water was obtained directly from a Milli-Q system equipped with a 5000 Da ultrafiltration cartridge. Reversed-phase high-performance liquid chromatography (HPLC) was used both for the analysis and purification of oligoribonucleotides using linear gradients of $0.1 \mathrm{M}$ aqueous $\mathrm{NH}_{4} \mathrm{HCO}_{3}$, and a 1:1 mixture of $0.1 \mathrm{M}$ aqueous $\mathrm{NH}_{4} \mathrm{HCO}_{3}$ and $\mathrm{ACN}$. Characterization was carried out by high resolution MALDI-TOF mass spectrometry (negative mode, 2,4,6-trihidroxyacetophenone matrix with ammonium citrate as an additive).

The following oligoribonucleotide sequences were synthesized $(*$ label denotes that the ends of the chains were modified with 2'-O-methylribonucleosides): wt RNA: 5'rG*C*GGCAGUGUGAGUACCUUCACACGUCC ${ }^{*} \mathrm{C}^{*}$; +3 mutated RNA: 5'rG* $\mathrm{C}^{*}$ GGCAGUGUAAAGUACCUUCACACGUCC*C*; +16 mutated RNA:

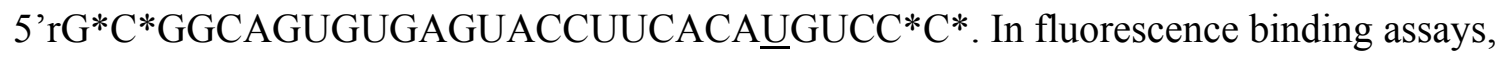
fluorescein was attached at the 5'-end of wt RNA, and the adenine in the loop of the +3 mutated RNA sequence was replaced by 2-AP. NMR titration experiments were carried out with a shorter wt RNA sequence: 5'rGGCAGUGUGAGUACCUUCACACGUC.

$\boldsymbol{U V}$-monitored melting experiments. Melting curves were recorded by cooling the samples from $90{ }^{\circ} \mathrm{C}$ to $20^{\circ} \mathrm{C}$ at a constant rate of $0.5^{\circ} \mathrm{C} \min ^{-1}$ and measuring the absorbance at $260 \mathrm{~nm}$ as a function of temperature. Then, the reverse denaturation curve $\left(20^{\circ} \mathrm{C}\right.$ to $\left.90{ }^{\circ} \mathrm{C}\right)$ was recorded. All experiments were repeated at least three times until coincident Tm values were obtained. The error in $\mathrm{T}_{\mathrm{m}}$ values was $\pm 0.2^{\circ} \mathrm{C}$. The solutions were $1 \mu \mathrm{M}$ both in RNA (wt, +3 or +16 ) and in ligands, in $10 \mathrm{mM}$ sodium phosphate buffer $\mathrm{pH} 6.8,50 \mathrm{mM} \mathrm{NaCl}$ and $0.1 \mathrm{mM} \mathrm{Na}_{2}$ EDTA.

Fluorescence binding assays. Fluorescence measurements were performed in $1 \mathrm{~cm}$ pathlength quartz cells on a Quanta-Master fluorometer (PTI) at $25^{\circ} \mathrm{C}$, with an excitation slit width of $10 \mathrm{~nm}$ and an emission slit width of $10 \mathrm{~nm}$. Upon excitation at $290 \mathrm{~nm}$, the emission spectrum was recorded over a range between 340 and $410 \mathrm{~nm}$ until no changes in the fluorescence intensity were detected. All binding assays were performed in the melting curves buffer with continuous magnetic stirring, except during the measurement.

For each experiment, the fluorescence spectrum of $600 \mu \mathrm{L}$ buffer solution without RNA or ligand was first taken, to be used as the baseline. Following this buffer blank, the spectrum of a $83 \mathrm{nM}$ solution of refolded RNA containing 2-AP $(600 \mu \mathrm{L})$ was recorded, and the 
baseline blank subtracted. Subsequent aliquots of $1 \mu \mathrm{L}$ of an aqueous ligand solution (increasing in concentration from 0 to $5.43 \mu \mathrm{M}$, depending on the ligand affinity) were added to the solution containing RNA, and the fluorescence spectrum was recorded after addition of each aliquot until the 2-AP fluorescence signal at $365 \mathrm{~nm}$ reached saturation (typically 5-10 $\mathrm{min}$ ). Over the entire range of ligand concentrations, the emission maxima varied less than $1 \mathrm{~nm}$. The total volume of the sample never changed more than $20 \%$. The full titration was repeated in the absence of labelled RNA to correct for the presence of the ligand's fluorescence. These spectra were subtracted from each corresponding point of the labelled RNA titrations, and the resulting fluorescence intensity was corrected for dilution $\left(\mathrm{F}^{*} \mathrm{~V} / \mathrm{V}_{0}\right)$. The emission fluorescence at $365 \mathrm{~nm}$ was normalized by dividing the difference between the observed fluorescence, $F_{o b}$, and the initial fluorescence, $F_{i}$, by the difference between the final fluorescence, $F_{f}$, and the initial fluorescence, $F_{i}: F_{N}=\left(F_{o b}-F_{i}\right) /\left(F_{f}-F_{i}\right)$. This normalized fluorescence intensity $\left(\mathrm{F}_{\mathrm{N}}\right)$ was plotted as a function of the logarithm of the total ligand concentration. Finally, nonlinear regression using a sigmoidal dose-response curve was performed with the software package GraphPad Prism 4 (GraphPad Software, San Diego, CA) to calculate the $\mathrm{EC}_{50}$ values. Experimental errors were less than or equal to $\pm 25 \%$ of each value.

NMR spectroscopy of $\boldsymbol{R} \boldsymbol{N A}$-ligand complexes. NMR spectra were acquired in a Bruker Advance spectrometer operating at $600 \mathrm{MHz}$ and equipped with a cryoprobe. Samples of the complexes were prepared by mixing the appropriate amounts of RNA and ligand and performing an annealing protocol consisting of heating to $90{ }^{\circ} \mathrm{C}$ for $3 \mathrm{~min}$, followed by snap cooling on ice for $20 \mathrm{~min}$. Samples were dissolved in $10 \mathrm{mM}$ sodium phosphate, $\mathrm{pH}$ 6.8, in a 9:1 $\mathrm{H}_{2} \mathrm{O}-\mathrm{D}_{2} \mathrm{O}$ mixture and NMR spectra were recorded at $5{ }^{\circ} \mathrm{C}$ to reduce the exchange with water. Water suppression was achieved by using an excitation sculpting sequence (zgesgp).

\section{Associated Content}

Supporting Information

1D $\left({ }^{1} \mathrm{H}\right.$ and $\left.{ }^{13} \mathrm{C}\right)$ and 2D NMR spectra of all compounds synthesized. Reversed-phase HPLC traces of the ligands. Fluorescence titration curves. This material is available free of charge via the Internet at http://pubs.acs.org. 


\section{Author Information}

Corresponding Author

*E-mail: vmarchan@ub.edu.

\section{Acknowledgments}

The authors wish to thank Prof. Enrique Pedroso for fruitful discussions on the design of Janus structures. This work was supported by funds from the Ministerio de Economia $y$ Competitividad (CTQ2010-21567-C02-01), the Generalitat de Catalunya (2009SGR-208) and the Programa d'Intensificació de la Recerca (UB). Gerard Artigas was a recipient fellow of the University of Barcelona. The authors acknowledge Dr Margarida Gairí from the Barcelona Scientific Park for NMR technical support, and Dr. Irene Fernández and Laura Ortiz from the facilities of the Servei d'Espectrometria de Masses of the University of Barcelona for MS support.

\section{References}

(1) (a) Zaman, G. J. R.; Michiels, P. J. A.; van Boeckel, C. A. A. Drug Discov. Today 2003, 8, 297. (b) Thomas, J. R.; Hergenrother, P. J. Chem. Rev. 2008, 108, 1171. (c) Aboul-ela, F. Future Med. Chem. 2010, 2, 93. (d) Guan, L.; Disney, M. D. ACS Chem. Biol. 2012, 7, 73. (2) (a) Stelzer, A. C.; Frank, A. T.; Kratz, J. D.; Swanson, M. D.; Gonzalez-Hernandez, M. J.; Lee, J.; Andricioaei, I.; Markovitz, D. M.; Al-Hashimi, M. Nat. Chem. Biol. 2011, 7, 553. (b) Ofori, L. O.; Hoskins, J.; Nakamori, M.; Thornton, C. A.; Miller, B. L. Nucleic Acids Res. 2012, 40, 6380. (c) Childs-Disney, J. L.; Parkesh, R.; Nakamori, M.; Thornton, C. A.; Disney, M. D. ACS Chem. Biol. 2012, 7, 1984. (d) Guan, L.; Disney, M. D. Angew. Chem. Int. Ed. 2013, 52, 1462.

(3) Moumné, R.; Catala, M.; Larue, V.; Micouin, L.; Tisné, C. Biochimie 2012, 94, 1607.

(4) Bryson, D. I.; Zhang, W.; McLendon, P. M.; Reineke, T. M.; Santos, W. L. ACS Chem. Biol. 2012, 7, 210.

(5) (a) Varani, G.; McClain, W. H. EMBO Rep. 2000, 1, 18. (b) Xu, D.; Landon, T.;

Greenbaum, N. L.; Fenley, M. O. Nucleic Acids Res. 2007, 35, 3836.

(6) Hermann, T.; Westhof, E. Chem. Biol. 1999, 6, R335.

(7) (a) Varnai, P.; Canalia, M.; Leroy, J.-L. J. Am. Chem. Soc. 2004, 126, 14659. (b) Lee, J.-H.; Pardi, A. Nucleic Acids Res. 2007, 35, 2965.

(8) Branda, N.; Kurz, G.; Lehn, J.-M. Chem. Commun. 1996, 2443. 
(9) (a) Chen, D.; Meena; Sharma, S. K.; McLaughlin, L. W. J. Am. Chem. Soc. 2004, 126,

70. (b) Chen, H.; Meena; McLaughlin, L. W. J. Am. Chem. Soc. 2008, 130, 13190. (c) Shin, D.; Tor, Y. J. Am. Chem. Soc. 2011, 133, 6926. (d) Zeng, Y.; Pratumyot; Y.; Piao, X.; Bong, D. J. Am. Chem. Soc. 2012, 134, 832.

(10) (a) Arambula, J. F.; Ramisetty, S. R.; Baranger, A. M.; Zimmerman, S. C. Proc. Nat. Acad. Sci. U.S.A. 2009, 106, 16068. (b) Jahromi, A. H.; Nguyen, L.; Fu, Y.; Miller, K. A.; Baranger, A. M.; Zimmerman, S. C. ACS Chem. Biol. 2013, 8, 1037.

(11) (a) López-Senín, P.; Gómez-Pinto, I.; Grandas, A.; Marchán, V. Chem. Eur. J. 2011, 17, 1946. (b) López-Senín, P.; Artigas, G.; Marchán, V. Org. Biomol. Chem. 2012, 10, 9243.

(12) (a) Varani, L.; Hasegawa, M.; Spillantini, M. G.; Smith, M. J.; Murrell, J. R.; Ghetti, B.; Klug, A.; Goedert, M.; Varani, G. Proc. Nat. Acad. Sci. U.S.A. 1999, 96, 8229. (b) Donahue, C. P.; Muratore, C.; Wu, J. Y.; Kosik, K. S.; Wolfe, M. S. J. Biol. Chem. 2006, $281,23302$.

(13) (a) Varani, L.; Spillantini, M. G.; Goedert, M.; Varani, G. Nucleic Acids Res. 2000, 28, 710. (b) Donahue, C. P.; Ni, J.; Rozners, E.; Glicksman, M. A.; Wolfe, M. S. J. Biomol. Screening 2007, 12, 789. (c) Zheng, S.; Chen, Y.; Donahue, C. P.; Wolfe, M. S.; Varani, G. ACS Chem. Biol. 2009, 16, 557. (d) Liu, Y.; Peacey, E.; Dickson, J.; Donahue, C. P.; Zheng, S.; Varani, G.; Wolfe, M. S. J. Med. Chem. 2009, 52, 6523.

(14) (a) Spillantini, M. G.; Murrell, J. R.; Goedert, M.; Farlow, M. R.; Klug, A. Proc. Natl. Acad. Sci. U.S.A. 1998, 95, 7737. (b) Liu, F.; Gong, C. X. Mol. Degener. 2008, 3:8. (c) Wolfe, M. S. J. Biol. Chem. 2009, 284, 6021.

(15) (a) Fenniri, H.; Deng, B.-L.; Ribbe, A. E.; Hallenga, K.; Jacob, J.; Thiyagarajan, P. Proc. Natl. Acad. Sci. U.S.A. 2002, 99, 6487. (b) Johnson, R. S.; Yamazaki, T.; Kovalenko, A.; Fenniri, H. J. Am. Chem. Soc. 2007, 129, 5735. (c) Tikhomirov, G.; Oderinde, M.; Makeiff, D.; Mansouri, A.; Lu, W.; Heirtzler, F.; Kwok, D. Y.; Fenniri, H. J. Org. Chem. 2008, 73, 4248.

(16) (a) Beingessner, R. L.; Díaz, J. A.; Hemraz, U. D.; Fenniri, H. Tetrahedron Lett. 2011, 52, 661. (b) Takeda Pharmaceutical Company Limited, Patent: US2011/152273A1, 2011.

(c) Slavish, P. J.; Price, J. E.; Hanumesh, P.; Webb, T. R. J. Comb. Chem. 2010, 12, 807.

(17) Von Angerer, S. "Product class 12: pyrimidines". Science of Synthesis, 2004, 16, 379.

(18) Prystas, M.; Sorm, F. Collection Czechoslov Chem. Commun. 1966, 31, 3990. 
(19) (a) Laliberté, D.; Maris, T.; Wuest, J. D. J. Org. Chem. 2004, 69, 1776. (b) Janczak, J.; Kubiak, R. J. Mol. Struct. 2005, 749, 60. (c) Asadi, A.; Patrick, B. O.; Perrin, D. M. J. Org. Chem. 2007, 72, 466.

(20) Mittapalli, G. K.; Reddy, K. R.; Xiong, H.; Munoz, O.; Han, B.; De Riccardis, F.; Krishnamurthy, R.; Eschenmoser, A. Angew. Chem. Int. Ed. 2007, 46, 2470.

(21) (a) Arya, D. P.; Xue, L.; Willis, B. J. Am. Chem. Soc. 2003, 125, 10148. (b) Blount, K. F.; Zhao, F.; Hermann, T.; Tor, Y. J. Am. Chem. Soc. 2005, 127, 9818.

(22) (a) Houghton, J. L.; Green, K. D.; Chen, W.; Garneau-Tsodikova, S. ChemBioChem 2010, 11, 880. (b) Becker, B.; Cooper, M. A. ACS Chem. Biol. 2013, 8, 105.

(23) (a) Luedtke, N. W.; Carmichael, P.; Tor, Y. J. Am. Chem. Soc. 2003, 125, 12374. (b) Luedtke, N. W.; Baker, T. J.; Goodman, M.; Tor, Y. J. Am. Chem. Soc. 2000, 122, 12035.

(c) Staple, D. W.; Venditti, V.; Niccolai, N.; Elson-Schwab, L.; Tor, Y.; Butcher, S. E. ChemBioChem 2008, 9, 93.

(24) Rabanal, F.; DeGrado, W. F.; Dutton, P. L. Tetrahedron Lett. 1996, 37, 1347.

(25) Grau-Campistany, A.; Massaguer, A.; Carrion-Salip, D.; Barragán, F.; Artigas, G.; López-Senín, P.; Moreno, V.; Marchán, V. Mol. Pharm. 2013, 10, 1964.

(26) (a) Warui, D. M.; Baranger, A. M. J. Med. Chem. 2009, 52, 5462. (b) Llano-Sotelo, B.; Chow, C. S. Bioorg. Med. Chem. Lett. 1999, 9, 213-216.

(27) Blakeley, B. D.; DePorter, S. M.; Mohan, U.; Burai, R.; Tolbert, B. S.; McNaughton, B. R. Tetrahedron 2012, 68, 8837.

(28) Sproat, B. S. in Methods in Molecular Biology. Oligonucleotide Synthesis: Methods and Applications, Vol. 288 (Ed. P. Herdewijn), Humana Press, Totowa, N.J., 2005, pp. 17-31. 